\title{
OPEN Gramicidin S and melittin: potential anti-viral therapeutic peptides to treat SARS-CoV-2 infection
}

\author{
Mohammed Ghalib Enayathullah ${ }^{1,2}$, Yash Parekh ${ }^{1,2}$, Sarena Banu ${ }^{1}$, Sushma Ram ${ }^{1}$, \\ Ramakrishnan Nagaraj ${ }^{1}$, Bokara Kiran Kumar ${ }^{1 \bowtie}$ \& Mohammed M. Idris ${ }^{1 \bowtie}$
}

The COVID19 pandemic has led to multipronged approaches for treatment of the disease. Since de novo discovery of drugs is time consuming, repurposing of molecules is now considered as one of the alternative strategies to treat COVID19. Antibacterial peptides are being recognized as attractive candidates for repurposing to treat viral infections. In this study, we describe the anti-SARS-CoV-2 activity of the well-studied antibacterial peptides gramicidin $\mathrm{S}$ and melittin obtained from Bacillus brevis and bee venom respectively. The $\mathrm{EC}_{50}$ values for gramicidin $S$ and melittin were $1.571 \mu \mathrm{g}$ and $0.656 \mu \mathrm{g}$ respectively based on in vitro antiviral assay. Significant decrease in the viral load as compared to the untreated group with no/very less cytotoxicity was observed. Both the peptides treated to the SARS-CoV- 2 infected Vero cells showed viral clearance from $12 \mathrm{~h}$ onwards with a maximal viral clearance after $24 \mathrm{~h}$ post infection. Proteomics analysis indicated that more than 250 proteins were differentially regulated in the gramicidin $S$ and melittin treated SARS-CoV-2 infected Vero cells against control SARS-CoV- 2 infected Vero cells after 24 and $48 \mathrm{~h}$ post infection. The identified proteins were found to be associated in the metabolic and mRNA processing of the Vero cells post-treatment and infection. Both these peptides could be attractive candidates for repurposing to treat SARS-CoV-2 infection.

The pandemic caused by SARS-CoV-2 has led to intense research not only on the biology of the virus but also therapeutic interventions with a multi-pronged approach ${ }^{1}$. Vaccines have been developed at "warp" speed. The overall efficacies of different vaccines, though variable are excellent ${ }^{2}$ and have played a major role in controlling the disease $e^{3}$. However, vaccines are not available universally and there have been cases of infection with SARSCoV-2 even in vaccinated individuals, though not severe 4 . Also, the effect of vaccines would wane over time. The vaccines may also be less effective against newly emerging strains such as omicron which has a very large number of substitutions in the viral genome as compared to the earlier strains (https://www.cdc.gov/coronavirus/ 2019-ncov/science/science-briefs/scientific-brief-omicron-variant.html). There is clearly a need for development of therapeutic agents in addition to vaccines. In the area of anti-infective agents against SARS-CoV-2, efforts have been taken to generate therapeutic antibodies that would neutralize the virus and prevent its interaction with cellular receptors to gain entry into cells ${ }^{5}$. Considering the time scales in developing a drug de novo, there have been several attempts to re-purpose drugs to treat COVID19 ${ }^{1,6,7}$. However, repurposed drugs have had very limited success in treating SARS-CoV-2 infection including remdesivir ${ }^{8}$. There is no drug to-date that can be used specifically to treat COVID19 disease. Although two drugs from Pfizer (Paxlovid) and Merck (Molnupiravir) appear to show promise, their effectiveness is still to be established unequivocally?

Infection in the case of SARS-CoV-2 is initiated by binding of the spike protein to ACE2 followed by a series of steps leading to fusion and internalization of the virus and propagation ${ }^{1,10}$. If the binding of the spike protein to ACE2 is prevented, then the virus will no longer be able to enter cells and propagate. SARS-CoV-2 is an enveloped virus where the RNA is encapsulated within a lipid vesicular structure with the spike protein decorating on the external side giving the "corona" appearance ${ }^{1,10}$. Disruption of the lipid structure would lead to the disintegration of the virus. Naturally occurring membrane-active peptides have potent antimicrobial activity which stems from their ability to disrupt bacterial membranes ${ }^{11,12}$. We have explored the antiviral activity of two extensively studied peptides, gramicidin S having the sequence: [cyclo-(Val-Orn-Leu-D-Phe-Pro)2] ${ }^{13}$ and the bee venom peptide, melittin having the sequence: GIGAVLKVLTTGLPALISWIKRKRQQ-amide ${ }^{14}$. We reasoned that if the peptides could destabilize the viral membrane, the virus would disintegrate and would thus be rendered inactive. The peptides could also conceivably bind to the spike protein and prevents its interaction with ACE2 or inhibit fusion. 
a.

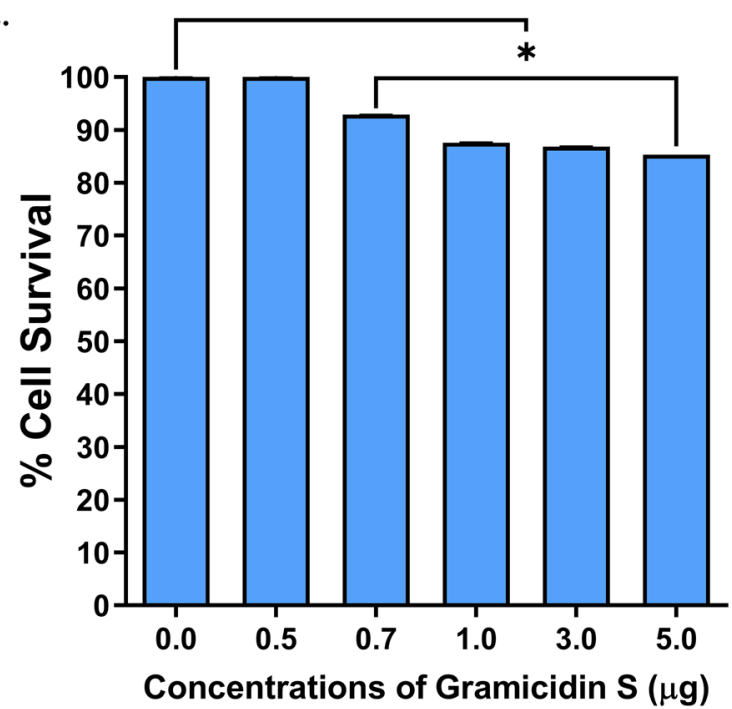

b.

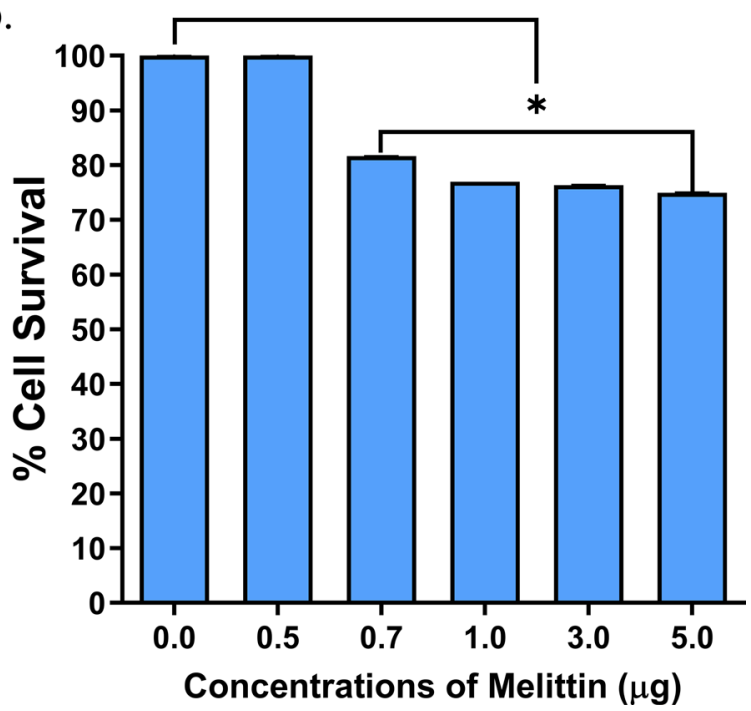

Figure 1. Measurement of Cytolytic activity of gramicidin $S$ and melittin using MTT Assay: The graphs represent the percentage of cell viability vs. concentrations of (a) Gramicidin S ( $\mu \mathrm{g})$. (b) Melittin $(\mu \mathrm{g})$. The values represent Mean \pm SD of atleast three independent experiments. The data analysis and graphs were generated using GraphPad Prism (Ver 8.4.2). Significance of variance, $\mathrm{p}<0.05$ is considered statistically significant.

Peptides are crucial components of host-defense against bacteria and fungi in species across the evolutionary scale ${ }^{11,12}$. There has been intense research in recent years to examine whether these and related peptides have the ability to neutralize SARS-CoV-2 and also have therapeutic potential ${ }^{12,15-17}$. They include naturally occurring peptides that can be easily isolated. Many of these peptides have also been investigated structurally. These include gramicidin $S$ and the bee venom peptide melittin ${ }^{13,14}$. The antiviral activity of melittin against several viruses has been investigated extensively ${ }^{18}$. Nano-conjugates of melittin with sitagliptin have been investigated for anti-SARS-CoV-2 activity ${ }^{19}$. Other pharmacological activities of melittin have also been investigated ${ }^{20,21}$. Gramicidin S has been used therapeutically to treat dental applications in humans ${ }^{22}$.

The antiviral activity of melittin has been reported previously. Hood et al., reported that melittin is highly effective in reducing HIV-1 infectivity ${ }^{23}$. Uddin et al., reported antiviral effect of melittin on different viruses (VSV-GFP, HSV-GFP, EV71, H3-GFP, RSV-GFP) both in vitro and in vivo ${ }^{24}$. Several studies showed melittin is effective against diverse array of viruses such as coxsackievirus, enterovirus, influenza A viruses, human immunodeficiency virus (HIV), herpes simplex virus (HSV), Junín virus (JV), respiratory syncytial virus (RSV), vesicular stomatitis virus (VSV), and tobacco mosaic virus (TMV) ${ }^{18}$. Not much scientific evidences or reports are available so far for the antiviral activity of the gramicidin S. Gramicidin S showed cell cytotoxicity (CC50) at $18.7 \mu \mathrm{g} / \mathrm{ml}$ in HT-29 cells ${ }^{25}$. Melittin showed CC50 of $6.45 \mu \mathrm{g} / \mathrm{ml}$ in C654 cells ${ }^{26}$.

We have investigated the antiviral activity of gramicidin $S$ and melittin against SARS-CoV-2 in vitro in detail. We have observed that both the peptides have the ability to neutralize the virus in an in vitro assay using Vero cells. At the $\mathrm{EC}_{50}$ value, there is no cytolytic activity. The viral load had decreased drastically in the treatment group as seen by confocal microscopic images. Proteomic analysis indicates that there is also a metabolic effect and not merely viral lysis. Both the peptides could be attractive candidates for development as therapeutic agents to treat SARS-CoV-2 infection. As the viral membrane would be a likely target, mutant strains may also be susceptible to the peptides.

\section{Results}

Antiviral activity of peptides. The cytolytic activity of gramicidin S and melittin was determined using MTT assay (Fig. 1). Results showed $75-80 \%$ cell survival at all the concentrations tested (up to $5 \mu \mathrm{g}$ ) indicating the safe use of these peptides (Fig. 1). The SARS-CoV-2 viral particles enumerated by the RT-qPCR showed that treatment of gramicidin $S$ and melittin effectively reduced viral load in vitro Log $\mathrm{EC}_{50}$ value of gramicidin $\mathrm{S}(0.1963)$ corresponds to $1.571 \mu \mathrm{g}$ and $\log \mathrm{EC}_{50}$ value (2.826) of melittin corresponds to $0.656 \mu \mathrm{g}$ (Fig. 2) The antiviral activity of gramicidin $\mathrm{S}(3.0 \mu \mathrm{g})$ and melittin $(1.5 \mu \mathrm{g})$ at 12 and $24 \mathrm{~h}$ was examined along with remdesi$\operatorname{vir}(1 \mu \mathrm{M})$ as assay control. The data shown in Fig. 3 indicates that the peptides show antiviral activity at $12 \mathrm{~h}$ and is more pronounced at $24 \mathrm{~h}$. The gramicidin S and melittin showed $99 \%$ and $95 \%$ viral reduction respectively at $12 \mathrm{~h}$ compared with remdesivir (20\%). At $24 \mathrm{~h}$ remdesivir showed $90 \%$ viral reduction whereas both gramicidin $\mathrm{S}$ and melittin showed $99 \%$ viral reduction. The SARS-CoV-2 antiviral activity of gramicidin S and melittin was compared with remdesivir by confocal microscopy (Fig. 4). Panel B (green fluorescence) indicates infection of cells, more prominent at $24 \mathrm{~h}$. Panels D and E correspond to virus incubated with gramicidin S and melittin before incubating with cells. The considerable decrease in green fluorescence indicates that both the peptides have good anti-viral activity as with remdesivir shown in Panel E. Although, antiviral activity is observed at $12 \mathrm{~h}$, it is more pronounced at $24 \mathrm{~h}$. 

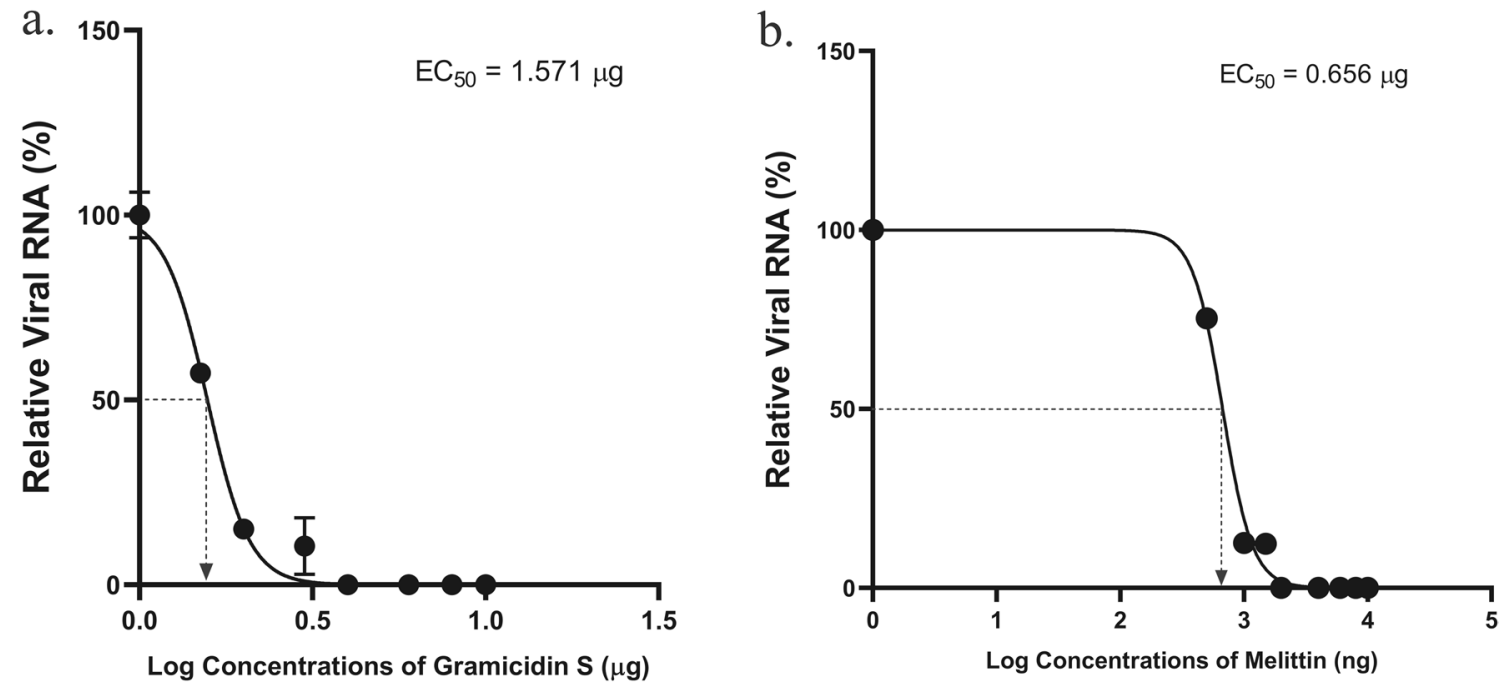

Figure 2. Anti SARS-CoV-2 activity of gramicidin S and melittin in vitro: (a). Relative viral RNA (\%) vs. Log concentrations of gramicidin S ( $\mu$ g). (b) Relative viral RNA (\%) vs. Log concentrations of melittin (ng). The graphs represent the $\mathrm{Ct}$ values of N-gene calculated using RT-qPCR in the supernatants. The $\log \mathrm{EC}_{50}$ value of gramicidin $\mathrm{S}(0.1963)$ corresponds to $1.571 \mu \mathrm{g}$ and $\mathrm{Log}_{\mathrm{EC}}$ value (2.826) of melittin corresponds to $0.656 \mu \mathrm{g}$ as shown in the graph.

a.

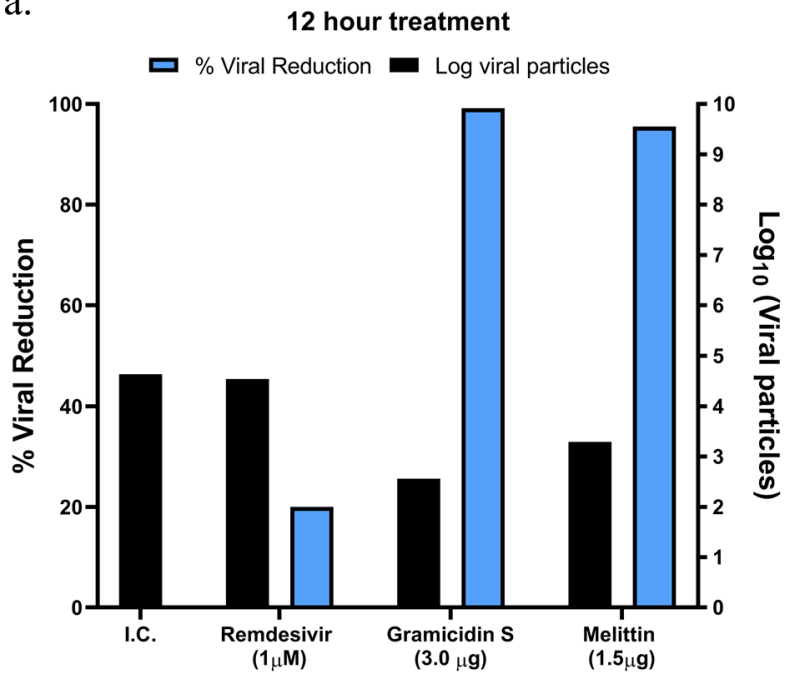

b.

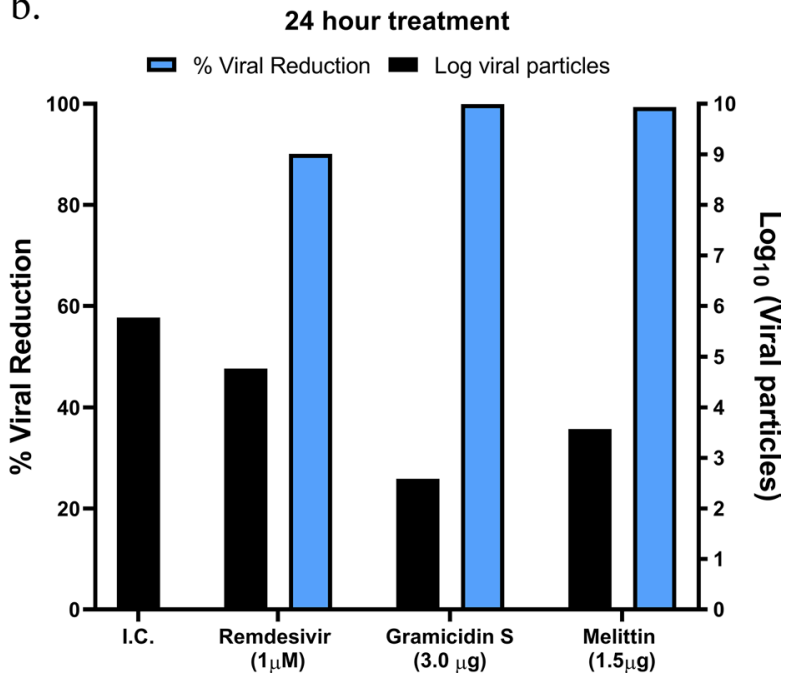

Figure 3. The anti SARS-CoV2 activity of remdesivir gramicidin S and melittin at 12 (a) and 24 (b) h post infection. The $\mathrm{X}$ axis represents different experimental groups: I.C (infection control), remdesivir $(1 \mu \mathrm{M})$, gramicidin $\mathrm{S}(3.0 \mu \mathrm{g})$, and melittin $(1.5 \mu \mathrm{g})$. The $\mathrm{Y}$ axis (Blue bars) represents \% of viral reduction and $\mathrm{Y}^{\prime}$-Axis (black bars) represents the $\log _{10}$ viral particles.

Proteomic analysis. The effect of the peptides on the ability of virus to infect Vero cells was studied by high-throughput proteomic analysis. iTRAQ based quantitative proteomics analysis identified 7 SARS-CoV-2 proteins as up regulated in the control infected Vero Cells. Nsp9, ORF1ab, ORF10 and nucleocapsid phosphoprotein were found to be up-regulated in the Vero cells after $24 \mathrm{~h}$ of infection, whereas the same proteins were found to be down regulated in the cells upon gramicidin $S$ and melittin treatment (Table 1). Similarly, at $48 \mathrm{~h}$ post infection (hpi), ORF1ab, S protein, nucleocapsid phosphoprotein, helicase and RNA-dependent RNA polymerase were found to be up-regulated in the infected Vero cells which were found to be down regulated in the gramicidin S and melittin treated Vero cells (Table 1).

Based on proteomics analysis, a total of 254 proteins were found to be differentially regulated and associated in infected and peptide treated Vero cells (Table 2 and Fig. 5a). It was found that majority of up and down regulated proteins were reversed with gramicidin S and melittin treatment at 24 and 48 hpi. RS28, K22E, K2C1, RL17 are few of the major down-regulated proteins which were found to be reversing their expression post peptide treatment. NPM, ACLY, CALX and F184B were found to be up-regulated in Vero cells after 24hpi, whereas peptide treatment showed reversal of the protein expression (Table 2). Heat map analysis showed that gramicidin $\mathrm{S}$ and melittin-treated cells at their respective time point post infection are rooted together against out rooting with 

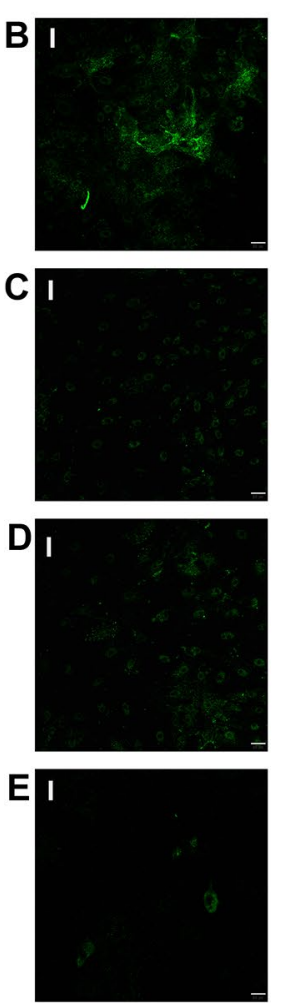
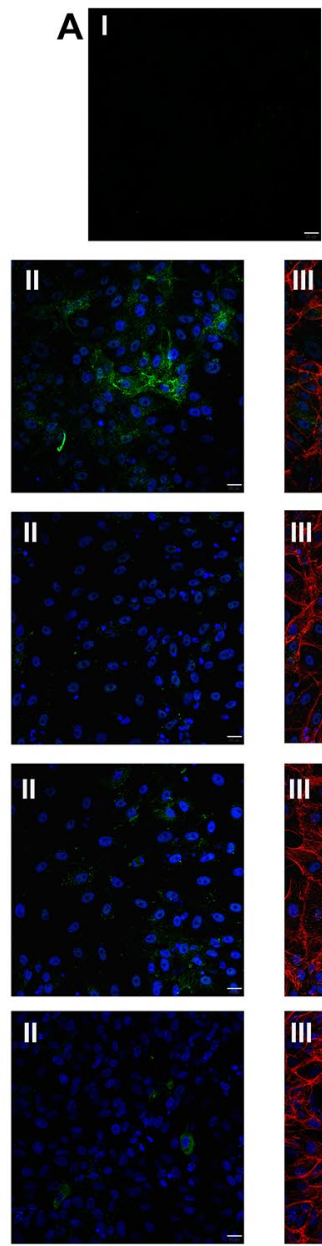
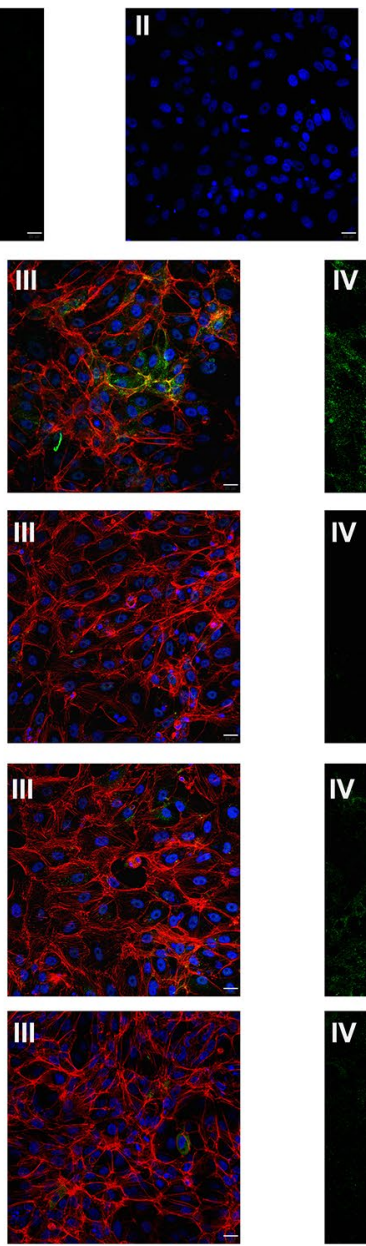
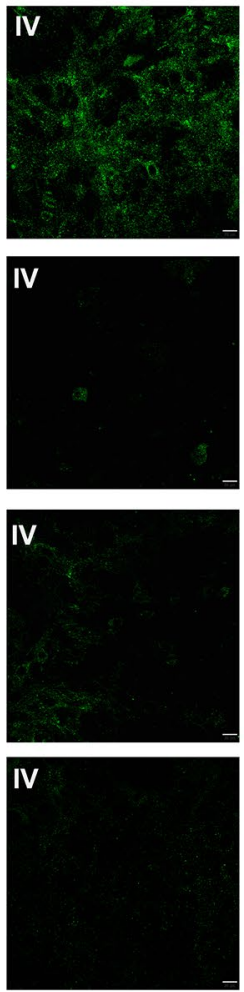
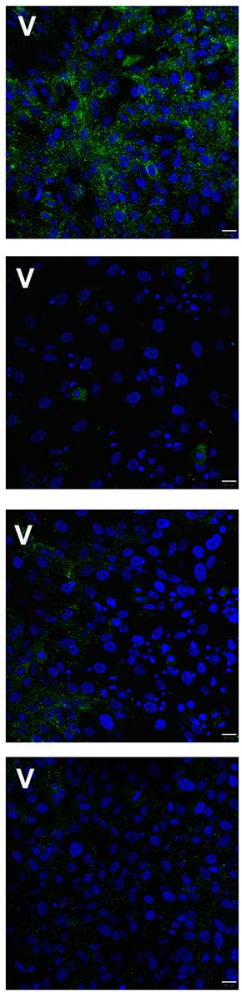
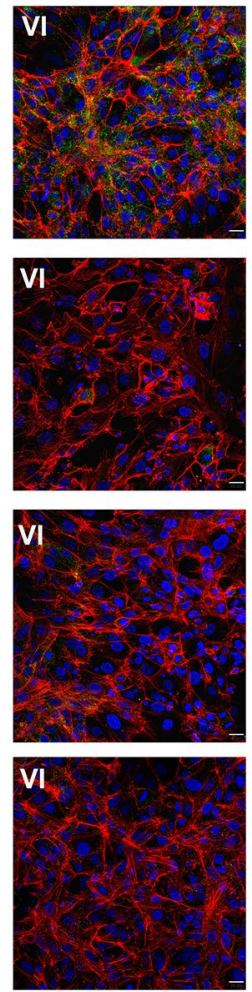

Figure 4. Immunofluorescence staining images against RBD protein expression specific to SARS-CoV-2 in Vero cells. (A) (I) Vero cells without SARS-CoV-2 infection (mock), (II) DAPI staining representing nucleus (blue); (III) Merged image of f-Actin (Phalloidin staining, red), nucleus (DAPI, blue). (B) Vero cells infected with SARS-CoV-2, (I) represents RBD protein expression (green) of SARS-CoV-2 virus at $12 \mathrm{~h}$; (II) DAPI staining representing nucleus (blue) along with RBD protein expression of SARS-CoV-2 (green) at $12 \mathrm{~h}$; (III) Merged image of f-Actin (red) (Phalloidin staining), nucleus (DAPI) and RBD protein of SARS-CoV-2 (green) at $12 \mathrm{~h}$; (IV) represents RBD protein expression (green) of SARS-CoV-2 virus at $24 \mathrm{~h}$; (V) DAPI staining representing nucleus (blue) along with RBD protein expression of SARS-CoV-2 (green) at $24 \mathrm{~h}$; (VI) Merged image of $\mathrm{f}$-Actin (Phalloidin staining, red), nucleus (DAPI, blue) and RBD protein of SARS-CoV-2 (green) at $24 \mathrm{~h}$. (C) Vero cells infected with SARS-CoV-2 treated with gramicidin S, (I) RBD protein expression (green) of SARS-CoV-2 virus at $12 \mathrm{~h}$; (II) DAPI staining representing nucleus (blue) along with RBD protein expression of SARS-CoV-2 (green) at $12 \mathrm{~h}$; (III) Merged image of f-Actin (red) (Phalloidin staining), nucleus (DAPI) and RBD protein of SARS-CoV-2 (green) at $12 \mathrm{~h}$; (IV) represents RBD protein expression (green) of SARS-CoV-2 virus at $24 \mathrm{~h}$; (V) DAPI staining representing nucleus (blue) along with RBD protein expression of SARS-CoV-2 (green) at $24 \mathrm{~h}$; (VI) Merged image f-Actin (Phalloidin staining, red), nucleus (DAPI, blue) and RBD protein of SARS-CoV-2 (green) at $24 \mathrm{~h}$. (D) Vero cells infected with SARS-CoV-2 treated with melittin. (I) represents RBD protein expression (green) of SARS-CoV-2 virus at $12 \mathrm{~h}$; (II) DAPI staining representing nucleus (blue) along with RBD protein expression of SARS-CoV-2 (green) at $12 \mathrm{~h}$; (III) Merged image of f-Actin (red) (Phalloidin staining), nucleus (DAPI) and RBD protein of SARS-CoV-2 (green) at $12 \mathrm{~h}$; (IV) represents RBD protein expression (green) of SARS-CoV-2 virus at $24 \mathrm{~h}$; (V) DAPI staining representing nucleus (blue) along with RBD protein expression of SARS-CoV-2 (green) at $24 \mathrm{~h}$; (VI) Merged image of f-Actin (Phalloidin staining, red), nucleus (DAPI, blue) and RBD protein of SARS-CoV-2 (green) at $24 \mathrm{~h}$. (E) Vero cells infected with SARS$\mathrm{CoV}-2$ treated with remdesivir, (I) represents RBD protein expression (green) of SARS-CoV-2 virus at $12 \mathrm{~h}$; (II) DAPI staining representing nucleus (blue) along with RBD protein expression of SARS-CoV-2 (green) at $12 \mathrm{~h}$; (III) Merged image of f-Actin (red) (Phalloidin staining), nucleus (DAPI) and RBD protein of SARS-CoV-2 (green) at $12 \mathrm{~h}$; (IV) represents RBD protein expression (green) of SARS-CoV-2 virus at $24 \mathrm{~h}$; (V) DAPI staining representing nucleus (blue) along with RBD protein expression of SARS-CoV-2 (green)at $24 \mathrm{~h}$; (VI) Merged image of f-Actin (Phalloidin staining, red), nucleus (DAPI, blue) and RBD protein of SARS-CoV-2 (green) at 24 h. Scale bars, $20 \mu \mathrm{m}(40 \times$ image $)$. 


\begin{tabular}{|c|c|c|c|c|c|c|c|}
\hline $\begin{array}{l}\text { Time } \\
\text { Point }\end{array}$ & $\begin{array}{c}\text { Protein } \\
\text { Accession No. }\end{array}$ & Protein Name & \# Peptides & $\begin{array}{c}\# \\
\text { PSMs }\end{array}$ & $\begin{array}{l}\text { Infected } \\
\text { Controls }\end{array}$ & $\begin{array}{c}\text { Gramicidin } \\
\text { S treated } \\
\text { Infected } \\
\text { cells }\end{array}$ & $\begin{array}{c}\text { Melittin } \\
\text { treated } \\
\text { Infected } \\
\text { cells }\end{array}$ \\
\hline \multirow{4}{*}{ 24hpi } & YP_009742616.1 & $\begin{array}{l}\text { nsp9 [Severe acute respiratory syndrome } \\
\text { coronavirus 2] }\end{array}$ & 17 & 69 & 0.1 & -1.2 & -0.9 \\
\hline & YP_009724389.1 & $\begin{array}{l}\text { ORF1ab polyprotein [Severe acute respiratory } \\
\text { syndrome coronavirus 2] }\end{array}$ & 762 & 3246 & 0.3 & -1.3 & -1.1 \\
\hline & YP_009725255.1 & $\begin{array}{l}\text { ORF10 protein [Severe acute respiratory } \\
\text { syndrome coronavirus 2] }\end{array}$ & 4 & 9 & 0.5 & -1.2 & -1.4 \\
\hline & YP_009724397.2 & $\begin{array}{l}\text { nucleocapsid phosphoprotein [Severe acute } \\
\text { respiratory syndrome coronavirus } 2 \text { ] }\end{array}$ & 71 & 260 & 0.6 & 0.1 & 1.6 \\
\hline \multirow{5}{*}{ 48hpi } & YP_009724389.1 & $\begin{array}{l}\text { ORF1ab polyprotein [Severe acute respiratory } \\
\text { syndrome coronavirus } 2 \text { ] }\end{array}$ & 755 & 3587 & 0.8 & -0.8 & -0.9 \\
\hline & YP_009724390.1 & $\begin{array}{l}\text { surface glycoprotein [Severe acute respiratory } \\
\text { syndrome coronavirus 2] }\end{array}$ & 108 & 418 & 0.1 & -1.3 & -0.7 \\
\hline & YP_009724397.2 & $\begin{array}{l}\text { nucleocapsid phosphoprotein [Severe acute } \\
\text { respiratory syndrome coronavirus 2] }\end{array}$ & 75 & 271 & 2.2 & -2.8 & -2.7 \\
\hline & YP_009725308.1 & $\begin{array}{l}\text { helicase [Severe acute respiratory syndrome } \\
\text { coronavirus 2] }\end{array}$ & 83 & 312 & 0.2 & -1.2 & -0.3 \\
\hline & YP_009725307.1 & $\begin{array}{l}\text { RNA-dependent RNA polymerase [Severe acute } \\
\text { respiratory syndrome coronavirus 2] }\end{array}$ & 106 & 492 & 0.9 & -1.0 & -1.6 \\
\hline
\end{tabular}

Table 1. List of SARS-CoV-2 proteins and their expression level in the vero cells post infection (control), gramicidin $S$ treatment and melittin treatment.

infected cells for the same time point post infection. It is very interesting to see the tight association of peptide treated Vero cell protein expression against control infected Vero cell protein expression for both the time points post infection (Fig. 5a).

A total of 125 proteins were selected for the Network and pathway analysis involving STRING v11.5. Based on Gene ontological functional enrichment analysis it was found that cellular process (125 proteins), biological regulation (108 proteins) and regulation of biological process (104 proteins) are the most highly associated biological processes; binding (113 proteins), proteins binding (87 proteins) and heterocyclic compound binding (84 proteins) are the most associated molecular functions and cellular anatomical entity (129 proteins), intracellular (125 proteins) and organelle (122 proteins) are the most occurred cellular components. Carbon metabolism (Blue color nodes), pentose phosphate pathway (Blue color nodes) and mRNA processing (Red color nodes) were most prominent local network cluster associated with STRING analysis (Fig. 5b). G6PD, PGK1, ALDOA, ALDOC, TKT, TALDO, LDHB, LDHA, PGAM1 and PGAM2 were the proteins which were found to be associated with carbon metabolism and pentose phosphate pathway analysis. Similarly TRA2B, RBMX, HNRPM, PTBP1, HNRPK, SRSF1, HNRPU, DDX5 and HNRPC proteins were found to be associated with mRNA processing pathway.

Interaction of gramicidin S and melittin with RBD domain of spike protein: In silico analysis. Both gramicidin $S$ and melittin are membrane-active peptides and exert their antimicrobial activity by interacting with membrane components ${ }^{13,14}$. Both the peptides may exert their antiviral activity by targeting multiple regions of the virus. The ability of the peptides to bind to the receptor binding domain (RBD) of the SARS-CoV-2 spike protein was examined by molecular docking using web version of the program $\mathrm{ZDOCK}^{27}$. The structures shown in Fig. 6 indicate that both gramicidin $S$ and melittin can bind to the RBD binding domain. Both the structures were in the top ten predictions in the ZDOCK output. Panel A shows the crystal structure of RBD-ACE2 complex. The interface between RBD and ACE are shown in violet color and stick representation respectively. The models of gramicidin S and melittin are shown in panels B and C respectively. The LigPlot ${ }^{28}$ of the interacting amino acids are shown in panels D for gramicidin $\mathrm{S}$ and $\mathrm{E}$ for melittin. The residues highlighted in yellow are involved in RBD binding to $\mathrm{ACE} 2^{10}$. The modeling study indicates that both the peptides can bind to RBD although their sequences are considerably different from the RBD binding region of ACE2. Both the peptides did not dock to the $\mathrm{N}$-terminal region of ACE2 that binds to RBD region of the spike protein in the top 10 predictions (data not shown).

\section{Discussion}

During the past two decades, the world had witnessed infection by three highly pathogenic human corona viruses namely, SARS-Co-V, MERS, SARS-CoV- $2^{29,30}$. They belong to the group of $\beta$-coronavirus and have the ability to cross animal-human barriers and cause serious illness in humans. The timely development of specific antivirals is of utmost importance. The development of vaccines at "warp speed" has led to decrease in mortality and serious illness caused by SARS-CoV- $2^{3}$. However, it is still not well established that whether vaccines are equally effective against the several variants that are emerging, such as the omicron variant, or the time frame when immunity will be present. To-date, there is no specific drug for SARS-CoV-2. Hence, there is clearly an urgent need to develop therapeutic molecules that would effectively neutralize the virus rather than repurposing drugs used to treat 


\begin{tabular}{|c|c|c|c|c|c|c|c|c|c|c|}
\hline \multirow[b]{2}{*}{$\begin{array}{l}\text { UNIPROT } \\
\text { ID }\end{array}$} & \multirow[b]{2}{*}{ Description } & \multirow[b]{2}{*}{ Symbol } & \multirow[b]{2}{*}{$\begin{array}{c}\# \\
\text { Peptides }\end{array}$} & \multirow[b]{2}{*}{ \# PSMs } & \multicolumn{3}{|c|}{24 hours post infection (hpi) } & \multicolumn{3}{|c|}{48 hours post infection (hpi) } \\
\hline & & & & & $\begin{array}{l}\text { Infected } \\
\text { controls }\end{array}$ & $\begin{array}{l}\text { Gramicidin S } \\
\text { treated } \\
\text { Infected cells }\end{array}$ & $\begin{array}{c}\text { Melittin } \\
\text { treated } \\
\text { Infected cells }\end{array}$ & $\begin{array}{l}\text { Infected } \\
\text { controls }\end{array}$ & $\begin{array}{l}\text { Gramicidin S } \\
\text { treated } \\
\text { Infected cells }\end{array}$ & $\begin{array}{c}\text { Melittin } \\
\text { treated } \\
\text { Infected cells }\end{array}$ \\
\hline O14744 & $\begin{array}{l}\text { Protein arginine } \mathrm{N} \text {-methyltransferase } 5 \mathrm{OS}=\text { Homo } \\
\text { sapiens OX=9606 GN=PRMT5 PE }=1 \mathrm{SV}=4 \text { - } \\
\text { [ANM5_HUMAN] }\end{array}$ & ANM5 & 7 & 9 & 0.1 & -1.4 & -0.9 & -0.9 & -0.9 & 0.7 \\
\hline O14818 & $\begin{array}{l}\text { Proteasome subunit alpha type-7 OS=Homo sapiens } \\
\text { OX=9606 GN=PSMA7 PE }=1 \text { SV=1 - [PSA7_HUMAN] }\end{array}$ & PSA7 & 5 & 7 & -0.3 & -1.8 & -0.7 & 0.2 & -0.1 & 0.1 \\
\hline O14979 & $\begin{array}{l}\text { Heterogeneous nuclear ribonucleoprotein D-like } \\
\text { OS=Homo sapiens OX=9606 GN=HNRNPDL PE }=1 \\
\text { SV }=3 \text { - [HNRDL_HUMAN] }\end{array}$ & HNRDL & 6 & 9 & 0.4 & -1.8 & -1.0 & 0.1 & -1.5 & 0.2 \\
\hline $\mathrm{O} 43175$ & $\begin{array}{l}\text { D-3-phosphoglycerate dehydrogenase OS=Homo } \\
\text { sapiens OX=9606 GN=PHGDH PE=1 SV=4 - } \\
\text { [SERA_HUMAN] }\end{array}$ & SERA & 5 & 6 & -0.4 & -1.0 & -0.3 & 1.0 & -0.3 & -1.2 \\
\hline O60218 & $\begin{array}{l}\text { Aldo-keto reductase family } 1 \text { member } \mathrm{B} 10 \mathrm{OS}=\mathrm{Homo} \\
\text { sapiens OX=9606 GN=AKR1B10 PE=1 SV=2 - } \\
\text { [AK1BA_HUMAN] }\end{array}$ & AK1BA & 6 & 7 & 1.4 & -0.8 & 1.5 & -0.9 & -0.2 & 0.2 \\
\hline O60318 & $\begin{array}{l}\text { Germinal-center associated nuclear protein OS=Homo } \\
\text { sapiens OX=9606 GN=MCM3AP PE }=1 \mathrm{SV}=2 \text { - } \\
\text { [GANP_HUMAN] }\end{array}$ & GANP & 16 & 18 & -0.4 & -1.0 & -0.3 & 0.1 & -1.6 & 0.0 \\
\hline O60701 & $\begin{array}{l}\text { UDP-glucose 6-dehydrogenase OS=Homo sapiens } \\
\text { OX=9606 GN=UGDH PE }=1 \mathrm{SV}=1 \text { - } \\
\text { [UGDH_HUMAN] }\end{array}$ & UGDH & 8 & 8 & -0.5 & -1.3 & -0.7 & 1.6 & -0.4 & -2.3 \\
\hline O75390 & $\begin{array}{l}\text { Citrate synthase, mitochondrial OS=Homo sapiens } \\
\text { OX }=9606 \mathrm{GN}=\mathrm{CS} \text { PE }=1 \mathrm{SV}=2 \text { - [CISY_HUMAN] }\end{array}$ & CISY & 8 & 10 & 1.4 & -0.6 & 1.4 & -1.1 & -1.0 & -0.7 \\
\hline O95359 & $\begin{array}{l}\text { Transforming acidic coiled-coil-containing protein } 2 \\
\text { OS=Homo sapiens OX=9606 GN=TACC2 } \mathrm{PE}=1 \mathrm{SV}=3 \\
\text { - [TACC2_HUMAN }]\end{array}$ & TACC2 & 14 & 18 & -1.0 & -1.4 & -1.7 & 1.3 & -1.0 & -1.5 \\
\hline O95831 & $\begin{array}{l}\text { Apoptosis-inducing factor } 1 \text {, mitochondrial OS=Homo } \\
\text { sapiens OX=9606 GN=AIFM1 PE=1 SV=1 - } \\
\text { [AIFM1_HUMAN] }\end{array}$ & AIFM1 & 9 & 11 & 0.1 & -2.0 & -0.9 & 1.0 & -0.6 & -1.5 \\
\hline P00338 & $\begin{array}{l}\text { L-lactate dehydrogenase A chain OS }=\text { Homo sapiens } \\
\text { OX }=9606 \mathrm{GN}=\mathrm{LDHA} \mathrm{PE}=1 \mathrm{SV}=2-[\mathrm{LDHA} \text { HUMAN] }\end{array}$ & LDHA & 14 & 29 & 1.3 & -1.2 & 0.7 & -1.5 & -1.6 & -1.7 \\
\hline P00352 & $\begin{array}{l}\text { Retinal dehydrogenase } 1 \text { OS }=\text { Homo sapiens OX }=9606 \\
\text { GN=ALDH1A1 PE }=1 \mathrm{SV}=2-[\text { [AL1A1_HUMAN] }\end{array}$ & AL1Al & 5 & 9 & 0.3 & -1.5 & -1.5 & -0.4 & -1.2 & 0.0 \\
\hline P00390 & $\begin{array}{l}\text { Glutathione reductase, mitochondrial OS=Homo sapiens } \\
\mathrm{OX}=9606 \mathrm{GN}=\mathrm{GSR} \mathrm{PE}=1 \mathrm{SV}=2-[\mathrm{GSHR} \text { HUMAN] }\end{array}$ & GSHR & 7 & 10 & 0.2 & -1.9 & -1.5 & -0.6 & -0.9 & 0.3 \\
\hline P00492 & $\begin{array}{l}\text { Hypoxanthine-guanine phosphoribosyltransferase } \\
\text { OS=Homo sapiens OX=9606 GN=HPRT1 PE=1 SV=2 - } \\
\text { [HPRT_HUMAN] }\end{array}$ & HPRT & 1 & 1 & 0.0 & -1.3 & -1.0 & 0.4 & -2.3 & -0.9 \\
\hline P00505 & $\begin{array}{l}\text { Aspartate aminotransferase, mitochondrial OS=Homo } \\
\text { sapiens OX=9606 GN=GOT2 PE=1 SV=3 - } \\
\text { [AATM_HUMAN] }\end{array}$ & AATM & 8 & 11 & 1.1 & -0.7 & 1.0 & -1.9 & -1.8 & -1.5 \\
\hline P00558 & $\begin{array}{l}\text { Phosphoglycerate kinase } 1 \text { OS=Homo sapiens OX=9606 } \\
\text { GN=PGK1 PE }=1 \text { SV }=3 \text { - [PGK1 HUMAN] }\end{array}$ & PGK1 & 19 & 33 & 1.4 & -0.7 & 1.6 & -1.6 & -1.8 & -2.2 \\
\hline P00966 & $\begin{array}{l}\text { Argininosuccinate synthase OS=Homo sapiens } \\
\text { OX }=9606 \mathrm{GN}=\mathrm{ASS} 1 \mathrm{PE}=1 \mathrm{SV}=2-[\text { ASSY_HUMAN }]\end{array}$ & ASSY & 6 & 6 & 0.7 & -1.3 & 0.6 & -1.3 & -0.3 & 0.6 \\
\hline P02545 & $\begin{array}{l}\text { Prelamin-A/C OS=Homo sapiens OX=9606 } \\
\text { GN=LMNA PE }=1 \text { SV }=1 \text { - [LMNA_HUMAN] }\end{array}$ & LMNA & 17 & 17 & -0.9 & -1.4 & -0.9 & 1.6 & -1.7 & -0.5 \\
\hline P02751 & $\begin{array}{l}\text { Fibronectin OS=Homo sapiens OX=9606 GN=FN1 } \\
\mathrm{PE}=1 \mathrm{SV}=4-[\mathrm{FINC} \text { HUMAN] }\end{array}$ & FINC & 18 & 24 & -1.2 & -1.2 & 0.6 & -0.2 & -0.8 & -1.3 \\
\hline P02768 & $\begin{array}{l}\text { Serum albumin OS=Homo sapiens OX=9606 GN=ALB } \\
\mathrm{PE}=1 \mathrm{SV}=2-\left[\mathrm{ALBU} \_ \text {HUMAN] }\right.\end{array}$ & ALBU & 9 & 15 & -1.7 & 1.1 & -0.3 & 0.5 & 0.5 & -1.7 \\
\hline P04075 & $\begin{array}{l}\text { Fructose-bisphosphate aldolase } \mathrm{A} \text { OS=Homo sapiens } \\
\text { OX=9606 GN=ALDOA PE }=1 \mathrm{SV}=2 \text { - } \\
\text { [ALDOA_HUMAN] }\end{array}$ & ALDOA & 21 & 36 & 1.2 & -0.6 & 1.3 & -1.7 & -1.6 & -1.3 \\
\hline P04083 & $\begin{array}{l}\text { Annexin } \mathrm{A} 1 \mathrm{OS}=\text { Homo sapiens } \mathrm{OX}=9606 \mathrm{GN}=\mathrm{ANXA1} \\
\mathrm{PE}=1 \mathrm{SV}=2-[\mathrm{ANXA1} \text { HUMAN] }\end{array}$ & ANXA1 & 18 & 36 & 0.6 & -0.4 & 1.4 & -1.4 & -1.2 & -1.7 \\
\hline P04179 & $\begin{array}{l}\text { Superoxide dismutase [Mn], mitochondrial OS=Homo } \\
\text { sapiens OX=9606 GN=SOD2 PE=1 SV=3 - } \\
\text { [SODM_HUMAN] }\end{array}$ & SOD2 & 6 & 12 & 0.4 & 0.6 & 0.7 & 2.2 & -1.1 & -1.5 \\
\hline P04264 & $\begin{array}{l}\text { Keratin, type II cytoskeletal } 1 \text { OS=Homo sapiens } \\
\text { OX }=9606 \mathrm{GN}=\mathrm{KRT} 1 \mathrm{PE}=1 \mathrm{SV}=6-[\mathrm{K} 2 \mathrm{Cl} \text { HUMAN }]\end{array}$ & $\mathrm{K} 2 \mathrm{Cl}$ & 32 & 63 & -2.6 & 0.1 & 0.5 & -0.6 & -0.9 & -0.7 \\
\hline P04406 & $\begin{array}{l}\text { Glyceraldehyde-3-phosphate dehydrogenase OS=Homo } \\
\text { sapiens OX=9606 GN=GAPDH PE }=1 \mathrm{SV}=3 \text { - } \\
\text { [G3P_HUMAN] }\end{array}$ & G3P & 19 & 67 & 1.4 & -0.9 & 1.4 & -1.9 & -1.5 & -1.9 \\
\hline P04792 & $\begin{array}{l}\text { Heat shock protein beta- } 1 \text { OS=Homo sapiens OX }=9606 \\
\text { GN }=H S P B 1 \text { PE }=1 \text { SV }=2-\left[\text { HSPB } 1 \_H U M A N\right]\end{array}$ & HSPB1 & 11 & 21 & -1.1 & -1.9 & -0.6 & 0.0 & -0.2 & -0.1 \\
\hline P05121 & $\begin{array}{l}\text { Plasminogen activator inhibitor } 1 \mathrm{OS}=\text { Homo sapiens } \\
\text { OX=9606 GN=SERPINE1 PE }=1 \mathrm{SV}=1 \text { - } \\
\text { [PAI1 HUMAN] }\end{array}$ & PAIl & 5 & 6 & -0.5 & -0.6 & -0.1 & -0.5 & -1.1 & 0.1 \\
\hline P05141 & $\begin{array}{l}\text { ADP/ATP translocase } 2 \text { OS }=\text { Homo sapiens OX }=9606 \\
\text { GN=SLC25A5 PE }=1 \text { SV }=7-[\text { ADT2_HUMAN }]\end{array}$ & ADT2 & 13 & 22 & -0.7 & -0.5 & -0.6 & -0.6 & -0.8 & 0.2 \\
\hline P05386 & $\begin{array}{l}\text { 60S acidic ribosomal protein P1 OS=Homo sapiens } \\
\text { OX=9606 GN=RPLP1 PE }=1 \text { SV=1 - [RLA1_HUMAN] }\end{array}$ & RLA1 & 1 & 7 & -1.9 & -1.2 & 0.9 & 2.6 & -1.8 & -2.7 \\
\hline P05388 & $\begin{array}{l}\text { 60S acidic ribosomal protein } \mathrm{P} 0 \text { OS=Homo sapiens } \\
\text { OX=9606 GN=RPLP0 PE }=1 \mathrm{SV}=1 \text { - [RLA0_HUMAN] }\end{array}$ & RLA0 & 10 & 24 & 1.2 & -0.2 & 1.7 & -1.4 & -1.6 & -2.0 \\
\hline P05783 & $\begin{array}{l}\text { Keratin, type I cytoskeletal } 18 \mathrm{OS}=\text { Homo sapiens } \\
\text { OX=9606 GN=KRT18 PE=1 SV=2 - } \\
\text { [K1C18_HUMAN] }\end{array}$ & K1C18 & 15 & 20 & -0.7 & -1.3 & -0.8 & -2.1 & -1.2 & -1.2 \\
\hline P06576 & $\begin{array}{l}\text { ATP synthase subunit beta, mitochondrial OS=Homo } \\
\text { sapiens OX=9606 GN=ATP5F1B PE=1 SV=3 - } \\
\text { [ATPB_HUMAN] }\end{array}$ & ATPB & 11 & 20 & 0.3 & -1.8 & -1.1 & 1.3 & -0.7 & -1.6 \\
\hline P06733 & $\begin{array}{l}\text { Alpha-enolase OS=Homo sapiens OX }=9606 \mathrm{GN}=\mathrm{ENO} 1 \\
\mathrm{PE}=1 \mathrm{SV}=2-[\mathrm{ENOA} \text { HUMAN] }\end{array}$ & ENOA & 23 & 45 & -0.6 & -1.6 & -0.4 & 1.2 & -0.5 & -1.9 \\
\hline P06744 & $\begin{array}{l}\text { Glucose-6-phosphate isomerase OS=Homo sapiens } \\
\mathrm{OX}=9606 \mathrm{GN}=\mathrm{GPI} P E=1 \mathrm{SV}=4-[\mathrm{G} 6 \mathrm{PI} \text { HUMAN }]\end{array}$ & G6PI & 6 & 10 & -0.1 & 0.0 & 1.9 & 2.0 & -1.8 & -0.8 \\
\hline P06748 & $\begin{array}{l}\text { Nucleophosmin OS=Homo sapiens OX }=9606 \\
\text { GN=NPM1 PE }=1 \text { SV=2 - [NPM_HUMAN] }\end{array}$ & NPM & 18 & 38 & 2.2 & -1.1 & 1.5 & -2.1 & -0.9 & -0.8 \\
\hline P06753 & $\begin{array}{l}\text { Tropomyosin alpha-3 chain OS="Homo sapiens } \\
\text { OX }=9606 \mathrm{GN}=\mathrm{TPM} 3 \mathrm{PE}=1 \mathrm{SV}=2-[\mathrm{TPM} 3 \text { HUMAN }]\end{array}$ & TPM3 & 13 & 22 & 1.3 & -1.2 & 0.8 & -1.5 & -1.0 & -1.1 \\
\hline
\end{tabular}

Table 2. (continued) 


\begin{tabular}{|c|c|c|c|c|c|c|c|c|c|c|}
\hline P07195 & $\begin{array}{l}\text { L-lactate dehydrogenase B chain OS=Homo sapiens } \\
\text { OX }=9606 \mathrm{GN}=\text { LDHB PE }=1 \mathrm{SV}=2 \text { - [LDHB_HUMAN] }\end{array}$ & LDHB & 16 & 22 & 1.5 & -1.1 & 1.1 & -1.9 & -1.2 & -1.4 \\
\hline P07237 & $\begin{array}{l}\text { Protein disulfide-isomerase OS=Homo sapiens } \\
\text { OX }=9606 \mathrm{GN}=\mathrm{P} 4 \mathrm{HB} P \mathrm{PE}=1 \mathrm{SV}=3-[\text { PDIA1_HUMAN }]\end{array}$ & PDIA1 & 13 & 17 & 0.0 & 0.1 & 2.7 & -0.2 & -1.5 & 0.1 \\
\hline P07305 & $\begin{array}{l}\text { Histone } \mathrm{H} 1.0 \mathrm{OS}=\text { Homo sapiens } \mathrm{OX}=9606 \mathrm{GN}=\mathrm{H} 1 \mathrm{~F} 0 \\
\mathrm{PE}=1 \mathrm{SV}=3-[\mathrm{H} 10 \text { HUMAN }]\end{array}$ & $\mathrm{H} 10$ & 1 & 2 & 0.2 & -0.4 & -0.4 & 0.2 & -1.8 & -0.8 \\
\hline P07355 & $\begin{array}{l}\text { Annexin A2 OS=Homo sapiens OX }=9606 \mathrm{GN}=\mathrm{ANXA} 2 \\
\mathrm{PE}=1 \mathrm{SV}=2-[\mathrm{ANXA2} \text { HUMAN] }\end{array}$ & ANXA2 & 37 & 100 & 1.4 & -0.6 & 1.4 & -2.0 & -1.2 & -1.6 \\
\hline P07437 & $\begin{array}{l}\text { Tubulin beta chain OS=Homo sapiens OX }=9606 \\
\text { GN }=\text { TUBB PE }=1 \text { SV }=2-[\text { TBB5 HUMAN }]\end{array}$ & TBB5 & 21 & 48 & -0.5 & -1.8 & -0.8 & 1.3 & -0.6 & -2.2 \\
\hline P07711 & $\begin{array}{l}\text { Cathepsin L1 OS=Homo sapiens OX }=9606 \mathrm{GN}=\mathrm{CTSL} \\
\mathrm{PE}=1 \mathrm{SV}=2-[\mathrm{CATL} 1 \text { HUMAN] }\end{array}$ & CATL1 & 8 & 11 & -0.2 & -1.6 & -0.8 & -0.1 & 0.3 & 0.2 \\
\hline P07737 & $\begin{array}{l}\text { Profilin-1 OS=Homo sapiens OX }=9606 \mathrm{GN}=\mathrm{PFN} 1 \\
\mathrm{PE}=1 \mathrm{SV}=2-\left[\mathrm{PROF} 1 \_ \text {HUMAN }\right]\end{array}$ & PROF1 & 4 & 6 & 0.9 & 0.7 & 0.9 & 2.3 & -1.9 & -3.1 \\
\hline P07910 & $\begin{array}{l}\text { Heterogeneous nuclear ribonucleoproteins } \mathrm{Cl} / \mathrm{C} 2 \\
\mathrm{OS}=\text { Homo sapiens OX }=9606 \mathrm{GN}=\mathrm{HNRNPC} \mathrm{PE}=1 \\
\mathrm{SV}=4-[\mathrm{HNRPC} \text { HUMAN] }\end{array}$ & HNRPC & 12 & 18 & 1.5 & -1.1 & 0.9 & -2.1 & -1.5 & -1.6 \\
\hline P08133 & $\begin{array}{l}\text { Annexin A6 OS }=\text { Homo sapiens OX }=9606 \mathrm{GN}=\mathrm{ANXA} 6 \\
\mathrm{PE}=1 \mathrm{SV}=3 \text { - }[\text { ANXA6 HUMAN }]\end{array}$ & ANXA6 & 12 & 14 & -0.6 & -0.8 & -1.1 & -0.3 & -1.1 & 0.1 \\
\hline P08238 & $\begin{array}{l}\text { Heat shock protein HSP } 90 \text {-beta } \mathrm{OS}=\text { Homo sapiens } \\
\text { OX=9606 GN=HSP90AB1 PE } 1 \mathrm{SV}=4 \text { - } \\
\text { [HS90B_HUMAN] }\end{array}$ & HS90B & 30 & 60 & 0.3 & -1.4 & -1.1 & -0.2 & 0.5 & -1.1 \\
\hline P08243 & $\begin{array}{l}\text { Asparagine synthetase [glutamine-hydrolyzing] } \\
\text { OS=Homo sapiens OX=9606 GN=ASNS PE }=1 \mathrm{SV}=4 \text { - } \\
\text { [ASNS_HUMAN] }\end{array}$ & ASNS & 4 & 4 & 0.0 & -1.9 & -0.9 & -1.4 & -0.3 & 0.9 \\
\hline P08670 & $\begin{array}{l}\text { Vimentin OS=Homo sapiens OX=9606 GN=VIM PE }=1 \\
\text { SV }=4-[\text { VIME_HUMAN] }\end{array}$ & $\begin{array}{l}\text { VIME } \\
\end{array}$ & 35 & 65 & -0.9 & -1.2 & -0.7 & 1.3 & -0.5 & -1.6 \\
\hline P08758 & $\begin{array}{l}\text { Annexin A5 OS }=\text { Homo sapiens OX }=9606 \mathrm{GN}=\mathrm{ANXA} 5 \\
\mathrm{PE}=1 \mathrm{SV}=2-[\mathrm{ANXA5} \text { HUMAN] }\end{array}$ & ANXA5 & 14 & 24 & -0.6 & -0.9 & -0.2 & -1.2 & -1.2 & -1.4 \\
\hline P08865 & $\begin{array}{l}\text { 40S ribosomal protein SA OS=Homo sapiens OX=9606 } \\
\text { GN=RPSA PE }=1 \mathrm{SV}=4-[\mathrm{RSSA} \text {.HUMAN] }\end{array}$ & RSSA & 7 & 14 & 0.4 & 0.2 & 1.5 & -1.2 & -0.8 & -2.8 \\
\hline P09211 & $\begin{array}{l}\text { Glutathione S-transferase } P \text { OS=Homo sapiens } \\
\text { OX=9606 GN=GSTP1 PE=1 SV=2 - } \\
\text { [GSTP1_HUMAN] }\end{array}$ & GSTP1 & 2 & 2 & -2.0 & -2.0 & 0.9 & 4.7 & -2.1 & -3.5 \\
\hline P09382 & $\begin{array}{l}\text { Galectin-1 OS=Homo sapiens OX=9606 GN=LGALS1 } \\
P E=1 \mathrm{SV}=2-[\text { LEG1_HUMAN] }\end{array}$ & LEG1 & 4 & 7 & -1.8 & -0.9 & 0.7 & 1.8 & -1.9 & -2.4 \\
\hline P09525 & $\begin{array}{l}\text { Annexin A4 OS=Homo sapiens OX }=9606 \mathrm{GN}=\mathrm{ANXA} 4 \\
\mathrm{PE}=1 \mathrm{SV}=4-[\mathrm{ANXA4} \text { HUMAN] }\end{array}$ & ANXA4 & 15 & 26 & 0.5 & -0.6 & 1.0 & 0.5 & -1.0 & -0.4 \\
\hline P09651 & $\begin{array}{l}\text { Heterogeneous nuclear ribonucleoprotein } \mathrm{A} 1 \mathrm{OS}=\mathrm{Homo} \\
\text { sapiens OX=9606 GN=HNRNPA1 PE }=1 \mathrm{SV}=5 \text { - } \\
{[\text { ROA1_HUMAN] }}\end{array}$ & ROA1 & 21 & 45 & -0.7 & -2.5 & -0.8 & -0.1 & -0.3 & 0.2 \\
\hline P09972 & $\begin{array}{l}\text { Fructose-bisphosphate aldolase } \mathrm{C} \text { OS }=\text { Homo sapiens } \\
\text { OX=9606 GN=ALDOC PE }=1 \mathrm{SV}=2 \text { - } \\
\text { [ALDOC HUMAN] }\end{array}$ & ALDOC & 6 & 15 & -0.4 & -1.1 & -1.5 & -2.1 & -1.0 & -1.2 \\
\hline P0CG48 & $\begin{array}{l}\text { Polyubiquitin-C OS }=\text { Homo sapiens OX=9606 GN=UBC } \\
P E=1 \text { SV }=3-[\text { UBC_HUMAN] }\end{array}$ & UBC & 8 & 10 & 1.1 & 0.2 & 1.3 & 2.6 & -1.6 & -1.9 \\
\hline P10412 & $\begin{array}{l}\text { Histone H1.4 OS=Homo sapiens OX=9606 } \\
\text { GN=HIST1H1E PE }=1 \mathrm{SV}=2-[\mathrm{H} 14 \text { HUMAN }]\end{array}$ & $\mathrm{H} 14$ & 13 & 18 & 1.1 & -0.1 & 1.9 & 0.5 & -1.9 & -2.3 \\
\hline P10809 & $\begin{array}{l}60 \mathrm{kDa} \text { heat shock protein, mitochondrial OS=Homo } \\
\text { sapiens OX=9606 GN=HSPD1 } \mathrm{PE}=1 \mathrm{SV}=2 \text { - } \\
\text { [CH6_HUMAN] }\end{array}$ & CH60 & 20 & 24 & -1.0 & 1.1 & 3.2 & 1.2 & -0.5 & -2.0 \\
\hline P11021 & $\begin{array}{l}\text { Endoplasmic reticulum chaperone } \mathrm{BiP} \text { OS=Homo } \\
\text { sapiens OX=9606 GN=HSPA5 } \mathrm{PE}=1 \mathrm{SV}=2 \text { - } \\
\text { [BIP_HUMAN] }\end{array}$ & BIP & 17 & 35 & -0.8 & -0.9 & 0.1 & 0.4 & -0.2 & -0.9 \\
\hline P11142 & $\begin{array}{l}\text { Heat shock cognate } 71 \mathrm{kDa} \text { protein OS=Homo sapiens } \\
\text { OX=9606 GN=HSPA8 PE }=1 \mathrm{SV}=1 \text { - } \\
\text { [HSP7C_HUMAN] }\end{array}$ & HSP7C & 22 & 31 & -0.1 & 0.2 & 2.4 & 1.6 & -1.2 & -1.8 \\
\hline P11413 & $\begin{array}{l}\text { Glucose-6-phosphate 1-dehydrogenase OS=Homo } \\
\text { sapiens OX=9606 GN=G6PD PE }=1 \mathrm{SV}=4 \text { - } \\
{[\text { G6PD HUMAN] }}\end{array}$ & G6PD & 6 & 12 & 0.0 & -2.1 & -0.9 & -2.0 & 0.4 & 1.2 \\
\hline P11586 & $\begin{array}{l}\text { C-1-tetrahydrofolate synthase, cytoplasmic OS }=\text { Homo } \\
\text { sapiens OX=9606 GN=MTHFD1 PE }=1 \mathrm{SV}=3 \text { - } \\
{[\text { C1TC_HUMAN] }}\end{array}$ & CITC & 10 & 11 & 0.4 & -0.8 & -0.9 & 0.1 & 0.4 & -0.4 \\
\hline P12236 & $\begin{array}{l}\text { ADP/ATP translocase } 3 \text { OS }=\text { Homo sapiens OX }=9606 \\
\text { GN }=\text { SLC25A6 PE }=1 \text { SV }=4-[\text { ADT3 HUMAN] }\end{array}$ & ADT3 & 5 & 9 & -0.2 & -0.8 & -1.4 & -0.1 & 0.5 & 0.2 \\
\hline P13489 & $\begin{array}{l}\text { Ribonuclease inhibitor OS=Homo sapiens OX=9606 } \\
\text { GN=RNH1 PE=1 SV=2 - [RINI HUMAN] }\end{array}$ & RINI & 3 & 6 & 1.6 & -1.2 & 0.8 & -1.7 & 0.0 & 0.8 \\
\hline $\mathrm{P} 13639$ & $\begin{array}{l}\text { Elongation factor } 2 \mathrm{OS}=\text { Homo sapiens } \mathrm{OX}=9606 \\
\mathrm{GN}=\mathrm{EEF} 2 \mathrm{PE}=1 \mathrm{SV}=4-[\mathrm{EF} 2 \text { HUMAN] }\end{array}$ & EF2 & 23 & 35 & 0.3 & -1.3 & -1.0 & -2.3 & 1.3 & 2.4 \\
\hline P13645 & $\begin{array}{l}\text { Keratin, type I cytoskeletal } 10 \mathrm{OS}=\text { Homo sapiens } \\
\text { OX=9606 GN=KRT10 PE }=1 \mathrm{SV}=6 \text { - } \\
\text { [K1C10_HUMAN] }\end{array}$ & $\mathrm{K} 1 \mathrm{C} 10$ & 22 & 41 & -0.9 & -1.0 & -1.0 & -0.3 & -1.4 & -1.1 \\
\hline P13647 & $\begin{array}{l}\text { Keratin, type II cytoskeletal } 5 \text { OS=Homo sapiens } \\
\text { OX=9606 GN=KRT5 PE=1 SV=3 - [K2C5_HUMAN }]\end{array}$ & $\mathrm{K} 2 \mathrm{C} 5$ & 15 & 17 & -0.9 & 0.1 & 2.4 & 1.8 & -0.4 & -2.4 \\
\hline P13667 & $\begin{array}{l}\text { Protein disulfide-isomerase A4 OS=Homo sapiens } \\
\text { OX }=9606 \text { GN=PDIA4 PE }=1 \mathrm{SV}=2 \text { - [PDIA4_HUMAN] }\end{array}$ & PDIA4 & 7 & 8 & 0.6 & -1.9 & -1.4 & -0.4 & -4.0 & -1.1 \\
\hline P14618 & $\begin{array}{l}\text { Pyruvate kinase PKM OS=Homo sapiens OX }=9606 \\
\text { GN=PKM PE }=1 \mathrm{SV}=4-[\mathrm{KPYM} \text { HUMAN] }\end{array}$ & KPYM & 28 & 44 & -0.7 & 0.2 & 2.3 & 1.6 & -0.8 & -2.5 \\
\hline P14625 & $\begin{array}{l}\text { Endoplasmin OS=Homo sapiens OX=9606 } \\
\mathrm{GN}=\mathrm{HSP} 90 \mathrm{~B} 1 \mathrm{PE}=1 \mathrm{SV}=1-[\text { ENPL_HUMAN] }\end{array}$ & ENPL & 20 & 31 & 0.4 & -1.4 & -1.3 & -3.3 & -0.9 & -1.1 \\
\hline P14868 & $\begin{array}{l}\text { Aspartate--tRNA ligase, cytoplasmic OS=Homo sapiens } \\
\text { OX }=9606 \mathrm{GN}=\text { DARS PE }=1 \mathrm{SV}=2 \text { - [SYDC HUMAN] }\end{array}$ & SYDC & 8 & 9 & 0.0 & -2.1 & -0.7 & -1.7 & 0.1 & 1.0 \\
\hline P15121 & $\begin{array}{l}\text { Aldose reductase OS=Homo sapiens OX=9606 } \\
\mathrm{GN}=\mathrm{AKR} 1 \mathrm{~B} 1 \mathrm{PE}=1 \mathrm{SV}=3-[\text { ALDR_HUMAN] }\end{array}$ & ALDR & 14 & 29 & 1.3 & -1.5 & 0.6 & -2.1 & -1.1 & -1.2 \\
\hline P15259 & $\begin{array}{l}\text { Phosphoglycerate mutase } 2 \text { OS=Homo sapiens } \\
\text { OX=9606 GN=PGAM2 PE=1 SV=3 - } \\
\text { [PGAM2 HUMAN] }\end{array}$ & PGAM2 & 6 & 7 & 0.3 & 0.6 & 0.9 & 0.0 & -1.6 & -0.7 \\
\hline P15559 & $\begin{array}{l}\text { NAD(P)H dehydrogenase [quinone] } 1 \mathrm{OS}=\text { Homo } \\
\text { sapiens OX=9606 GN=NQO1 PE=1 SV=1 - } \\
\text { [NQO1_HUMAN] }\end{array}$ & NQO1 & 3 & 4 & -0.2 & -1.4 & -1.4 & -0.1 & 0.1 & -0.2 \\
\hline $\mathrm{P} 15880$ & $\begin{array}{l}\text { 40S ribosomal protein S2 OS=Homo sapiens OX=9606 } \\
\mathrm{GN}=\mathrm{RPS} 2 \mathrm{PE}=1 \mathrm{SV}=2-[\mathrm{RS} 2 \text { HUMAN] }\end{array}$ & RS2 & 14 & 17 & -0.6 & -1.3 & -0.3 & -0.4 & 0.4 & 0.3 \\
\hline P16152 & $\begin{array}{l}\text { Carbonyl reductase [NADPH] } 1 \text { OS=Homo sapiens } \\
\text { OX=9606 GN=CBR1 PE }=1 \mathrm{SV}=3 \text { - [CBR1 HUMAN] }\end{array}$ & NADPH & 8 & 11 & 1.2 & -0.4 & 1.7 & 0.0 & 0.2 & 0.1 \\
\hline P17844 & $\begin{array}{l}\text { Probable ATP-dependent RNA helicase DDX5 } \\
\text { OS=Homo sapiens OX=9606 GN=DDX5 PE=1 SV=1 - } \\
\text { [DDX5 HUMAN] }\end{array}$ & DDX5 & 12 & 15 & -0.9 & 0.3 & 2.2 & 0.4 & -1.9 & -0.1 \\
\hline
\end{tabular}

Table 2. (continued) 


\begin{tabular}{|c|c|c|c|c|c|c|c|c|c|c|}
\hline P17987 & $\begin{array}{l}\text { T-complex protein } 1 \text { subunit alpha OS=Homo sapiens } \\
\text { OX=9606 GN=TCP1 PE=1 SV=1 - [TCPA_HUMAN] }\end{array}$ & TCPA & 6 & 7 & 0.1 & -1.8 & -1.1 & 1.4 & -2.9 & -1.2 \\
\hline P18124 & $\begin{array}{l}\text { 60S ribosomal protein L7 OS=Homo sapiens OX=9606 } \\
\text { GN=RPL7 PE=1 SV }=1-[\text { RL7 HUMAN] }\end{array}$ & RL7 & 9 & 11 & 0.0 & 0.5 & 1.3 & 1.1 & -1.8 & -1.4 \\
\hline P18621 & $\begin{array}{l}\text { 60S ribosomal protein } \mathrm{L} 17 \mathrm{OS}=\text { Homo sapiens } \mathrm{OX}=9606 \\
\mathrm{GN}=\mathrm{RPL} 17 \mathrm{PE}=1 \mathrm{SV}=3-[\mathrm{RL} 17 \text { HUMAN] }\end{array}$ & RL17 & 3 & 4 & -2.0 & -1.5 & 0.3 & -2.7 & 1.7 & 4.2 \\
\hline P18669 & $\begin{array}{l}\text { Phosphoglycerate mutase } 1 \text { OS }=\text { Homo sapiens } \\
\text { OX=9606 GN=PGAM1 PE }=1 \mathrm{SV}=2 \text { - } \\
\text { [PGAM1 HUMAN] }\end{array}$ & PGAM1 & 6 & 7 & -0.4 & -1.5 & -1.2 & -0.8 & 0.4 & 0.7 \\
\hline $\mathrm{P} 19105$ & $\begin{array}{l}\text { Myosin regulatory light chain } 12 \mathrm{~A} \mathrm{OS}=\text { Homo sapiens } \\
\text { OX=9606 GN=MYL12A PE }=1 \mathrm{SV}=2 \text { - } \\
\text { [ML12A_HUMAN] }\end{array}$ & ML12A & 4 & 8 & -0.6 & -1.2 & -0.2 & 1.0 & -1.0 & -1.8 \\
\hline P19338 & $\begin{array}{l}\text { Nucleolin OS=Homo sapiens OX=9606 GN=NCL PE }=1 \\
\text { SV }=3-[\text { NUCL_HUMAN] }\end{array}$ & NUCL & 11 & 14 & 0.5 & -1.3 & -1.1 & 0.2 & 0.6 & -0.8 \\
\hline P20073 & $\begin{array}{l}\text { Annexin A7 OS=Homo sapiens OX=9606 GN=ANXA7 } \\
\text { PE }=1 \text { SV }=3 \text { - [ANXA7 HUMAN] }\end{array}$ & ANXA7 & 6 & 7 & 0.1 & -1.6 & -1.2 & -1.0 & -2.1 & -1.7 \\
\hline P21291 & $\begin{array}{l}\text { Cysteine and glycine-rich protein } 1 \mathrm{OS}=\text { Homo sapiens } \\
\text { OX=9606 GN=CSRP1 PE }=1 \mathrm{SV}=3 \text { - } \\
\text { [CSRP1 HUMAN] }\end{array}$ & CSRP1 & 5 & 7 & -0.8 & -0.9 & -0.8 & -1.6 & 0.5 & 1.1 \\
\hline P21333 & $\begin{array}{l}\text { Filamin-A OS=Homo sapiens OX=9606 GN=FLNA } \\
P E=1 \mathrm{SV}=4-[\text { FLNA HUMAN] }\end{array}$ & FLNA & 26 & 38 & 0.1 & -1.0 & -0.9 & -0.5 & 1.0 & -1.6 \\
\hline P22087 & $\begin{array}{l}\text { rRNA 2'-O-methyltransferase fibrillarin OS=Homo } \\
\text { sapiens OX=9606 GN=FBL PE }=1 \mathrm{SV}=2 \text { - } \\
\text { [FBRL_HUMAN] }\end{array}$ & FBRL & 10 & 15 & 1.1 & -0.3 & 1.7 & -1.0 & -2.1 & -2.0 \\
\hline P22392 & $\begin{array}{l}\text { Nucleoside diphosphate kinase B OS=Homo sapiens } \\
\text { OX=9606 GN=NME2 PE=1 SV=1 - [NDKB_HUMAN] }\end{array}$ & NDKB & 6 & 11 & -1.6 & -1.2 & 0.8 & 1.9 & -2.0 & -3.0 \\
\hline P22626 & $\begin{array}{l}\text { Heterogeneous nuclear ribonucleoproteins } \mathrm{A} 2 / \mathrm{B} 1 \\
\mathrm{OS}=\text { Homo sapiens OX }=9606 \mathrm{GN}=\mathrm{HNRNPA} \mathrm{B} 1 \mathrm{PE}=1 \\
\mathrm{SV}=2-[\mathrm{ROA} 2 \text { HUMAN }]\end{array}$ & ROA2 & 12 & 23 & 1.0 & -1.0 & 0.8 & -1.9 & -2.1 & -2.7 \\
\hline P23284 & $\begin{array}{l}\text { Peptidyl-prolyl cis-trans isomerase B OS=Homo sapiens } \\
\text { OX=9606 GN=PPIB PE }=1 \text { SV=2 - [PPIB_HUMAN] }\end{array}$ & PPIB & 3 & 6 & -0.7 & -1.1 & -0.5 & -1.7 & 0.7 & 1.4 \\
\hline P23396 & $\begin{array}{l}\text { 40S ribosomal protein } \mathrm{S} 3 \mathrm{OS}=\text { Homo sapiens OX=9606 } \\
\mathrm{GN}=\mathrm{RPS} 3 \mathrm{PE}=1 \mathrm{SV}=2-[\mathrm{RS} 3 \text { HUMAN] }\end{array}$ & RS3 & 8 & 10 & 0.9 & 0.4 & 2.1 & -1.6 & 0.2 & 0.4 \\
\hline P23526 & $\begin{array}{l}\text { Adenosylhomocysteinase OS }=\text { Homo sapiens OX }=9606 \\
\text { GN }=\text { AHCY PE }=1 \text { SV }=4-[\text { AHH HUMAN] }\end{array}$ & SAHH & 7 & 11 & 0.9 & -0.4 & 1.6 & -1.2 & -1.5 & -1.6 \\
\hline $\mathrm{P} 23528$ & $\begin{array}{l}\text { Cofilin-1 OS=Homo sapiens OX }=9606 \mathrm{GN}=\mathrm{CFL} 1 \mathrm{PE}=1 \\
\text { SV }=3-[\mathrm{COF} 1 \text { HUMAN] }\end{array}$ & COF1 & 3 & 6 & -1.8 & -0.6 & 0.2 & 3.2 & -1.7 & -2.8 \\
\hline P24534 & $\begin{array}{l}\text { Elongation factor 1-beta OS=Homo sapiens OX=9606 } \\
\mathrm{GN}=\mathrm{EEF} 1 \mathrm{~B} 2 \mathrm{PE}=1 \mathrm{SV}=3-[\mathrm{EF} 1 \mathrm{~B} \text { HUMAN] }\end{array}$ & EF1B & 4 & 6 & 1.9 & -1.1 & 1.2 & -1.7 & -1.3 & -1.7 \\
\hline $\mathrm{P} 25705$ & $\begin{array}{l}\text { ATP synthase subunit alpha, mitochondrial OS=Homo } \\
\text { sapiens OX=9606 GN=ATP5F1A PE }=1 \mathrm{SV}=1 \text { - } \\
\text { [ATPA HUMAN] }\end{array}$ & ATPA & 14 & 15 & -0.5 & 0.2 & 2.2 & -0.2 & -1.2 & 0.2 \\
\hline P25786 & $\begin{array}{l}\text { Proteasome subunit alpha type-1 OS=Homo sapiens } \\
\text { OX=9606 GN=PSMA1 PE }=1 \mathrm{SV}=1 \text { - [PSA1 HUMAN] }\end{array}$ & PSAl & 5 & 7 & 1.4 & -0.7 & 1.3 & -1.9 & -1.2 & -1.3 \\
\hline P25788 & $\begin{array}{l}\text { Proteasome subunit alpha type-3 OS=Homo sapiens } \\
\text { OX=9606 GN=PSMA3 PE }=1 \mathrm{SV}=2 \text { - [PSA3_HUMAN] }\end{array}$ & PSA3 & 5 & 6 & -0.6 & -1.4 & -0.4 & -0.9 & -0.2 & 0.5 \\
\hline P26038 & $\begin{array}{l}\text { Moesin OS=Homo sapiens OX=9606 GN=MSN PE=1 } \\
\mathrm{SV}=3-[\text { MOES HUMAN] }\end{array}$ & MOES & 8 & 10 & 0.5 & -2.1 & -1.3 & 1.8 & -1.9 & -0.9 \\
\hline P26373 & $\begin{array}{l}\text { 60S ribosomal protein } \mathrm{L} 13 \mathrm{OS}=\text { Homo sapiens OX }=9606 \\
\mathrm{GN}=\mathrm{RPL} 13 \mathrm{PE}=1 \mathrm{SV}=4-[\mathrm{RL} 13 \text { HUMAN] }\end{array}$ & RL13 & 11 & 19 & -0.9 & -1.4 & -0.3 & -0.5 & 0.7 & 0.3 \\
\hline P26599 & $\begin{array}{l}\text { Polypyrimidine tract-binding protein } 1 \mathrm{OS}=\text { Homo } \\
\text { sapiens OX=9606 GN=PTBP1 PE=1 SV=1 - } \\
\text { [PTBP1_HUMAN] }\end{array}$ & PTBP1 & 8 & 13 & 0.2 & -1.7 & -1.1 & -0.5 & -1.1 & 0.3 \\
\hline P26641 & $\begin{array}{l}\text { Elongation factor 1-gamma OS=Homo sapiens } \\
\text { OX }=9606 \mathrm{GN}=\mathrm{EEF} 1 \mathrm{G} \text { PE }=1 \mathrm{SV}=3-[\mathrm{EF} 1 \mathrm{G} \text { HUMAN }]\end{array}$ & EF1G & 9 & 11 & 0.2 & -1.6 & -1.0 & -1.2 & -0.6 & 0.9 \\
\hline P27348 & $\begin{array}{l}\text { 14-3-3 protein theta OS }=\text { Homo sapiens OX }=9606 \\
\mathrm{GN}=\mathrm{YWHAQ} \mathrm{PE}=1 \mathrm{SV}=1-[1433 \mathrm{~T} \text { HUMAN }]\end{array}$ & $1433 \mathrm{~T}$ & 6 & 14 & -0.3 & -0.9 & -2.1 & 1.1 & -1.1 & -1.2 \\
\hline P27797 & $\begin{array}{l}\text { Calreticulin OS=Homo sapiens OX }=9606 \mathrm{GN}=\mathrm{CALR} \\
\mathrm{PE}=1 \mathrm{SV}=1-\text { [CALR HUMAN] }\end{array}$ & CALR & 7 & 8 & -0.1 & -2.7 & -1.0 & -1.7 & -0.1 & 0.7 \\
\hline P27824 & $\begin{array}{l}\text { Calnexin OS }=\text { Homo sapiens OX }=9606 \mathrm{GN}=\mathrm{CANX} \\
\mathrm{PE}=1 \mathrm{SV}=2-[\mathrm{CALX} \text { HUMAN }]\end{array}$ & CALX & 5 & 7 & 1.9 & -1.4 & -2.1 & -0.4 & 1.1 & -1.1 \\
\hline P28066 & $\begin{array}{l}\text { Proteasome subunit alpha type-5 OS=Homo sapiens } \\
\text { OX=9606 GN=PSMA } 5 E=1 \mathrm{SV}=3 \text { - [PSA5 HUMAN] }\end{array}$ & PSA5 & 2 & 3 & -0.2 & -0.9 & -1.2 & 0.3 & -0.2 & -0.1 \\
\hline P28074 & $\begin{array}{l}\text { Proteasome subunit beta type-5 OS=Homo sapiens } \\
\text { OX }=9606 \mathrm{GN}=\mathrm{PSMB} 5 \mathrm{PE}=1 \mathrm{SV}=3 \text { - [PSB5 HUMAN }\end{array}$ & PSB5 & 8 & 12 & -0.9 & -1.6 & -0.4 & 2.1 & -1.6 & -2.1 \\
\hline P28838 & $\begin{array}{l}\text { Cytosol aminopeptidase OS }=\text { Homo sapiens OX }=9606 \\
\text { GN=LAP3 PE }=1 \text { SV }=3 \text { - [AMPL HUMAN] }\end{array}$ & AMPL & 12 & 17 & -0.4 & -1.5 & -0.5 & 1.0 & -0.5 & -1.6 \\
\hline P29401 & $\begin{array}{l}\text { Transketolase OS=Homo sapiens OX }=9606 \mathrm{GN}=\mathrm{TKT} \\
\mathrm{PE}=1 \mathrm{SV}=3-[\mathrm{TKT} \text { HUMAN] }\end{array}$ & TKT & 15 & 17 & -0.3 & 0.2 & 2.6 & 1.8 & -1.0 & -3.1 \\
\hline P29692 & $\begin{array}{l}\text { Elongation factor 1-delta OS }=\text { Homo sapiens OX=9606 } \\
\mathrm{GN}=\mathrm{EEF} 1 \mathrm{D} \text { PE }=1 \mathrm{SV}=5-[\mathrm{EF} 1 \mathrm{D} \text { HUMAN] }\end{array}$ & EFID & 9 & 9 & -0.2 & -2.8 & -0.6 & -0.8 & -0.8 & -0.7 \\
\hline P30041 & $\begin{array}{l}\text { Peroxiredoxin-6 OS }=\text { Homo sapiens OX=9606 } \\
\text { GN=PRDX6 PE }=1 \text { SV }=3 \text { - [PRDX6 HUMAN] }\end{array}$ & PRDX6 & 8 & 11 & -0.7 & -1.1 & -0.1 & -1.5 & 0.1 & 0.6 \\
\hline P30048 & $\begin{array}{l}\text { Thioredoxin-dependent peroxide reductase, } \\
\text { mitochondrial OS=Homo sapiens OX=9606 } \\
\text { GN=PRDX3 PE=1 SV=3 - [PRDX3 HUMAN] }\end{array}$ & PRDX3 & 3 & 5 & -1.2 & -2.0 & -0.5 & 2.6 & -1.5 & -2.3 \\
\hline P30101 & $\begin{array}{l}\text { Protein disulfide-isomerase A3 OS=Homo sapiens } \\
\text { OX }=9606 \text { GN }=\text { PDIA3 PE }=1 \text { SV }=4 \text { - [PDIA3 HUMAN] }\end{array}$ & PDIA3 & 9 & 16 & 0.2 & -1.8 & -1.3 & 0.8 & -0.5 & -1.3 \\
\hline P30419 & $\begin{array}{l}\text { Glycylpeptide N-tetradecanoyltransferase } 1 \mathrm{OS}=\text { Homo } \\
\text { sapiens OX=9606 GN=NMT1 PE }=1 \mathrm{SV}=2 \text { - } \\
\text { [NMT1 HUMAN] }\end{array}$ & NMT1 & 5 & 7 & 0.2 & -0.5 & -0.9 & 0.1 & -1.8 & -0.4 \\
\hline P31943 & $\begin{array}{l}\text { Heterogeneous nuclear ribonucleoprotein } \mathrm{H} \text { OS }=\text { Homo } \\
\text { sapiens OX=9606 GN }=\text { HNRNPH1 PE }=1 \mathrm{SV}=4 \text { - } \\
\text { [HNRH1 HUMAN] }\end{array}$ & HNRH1 & 15 & 29 & -0.6 & -1.5 & -0.2 & -0.7 & -0.9 & 0.6 \\
\hline P31946 & $\begin{array}{l}\text { 14-3-3 protein beta/alpha OS }=\text { Homo sapiens OX }=9606 \\
\mathrm{GN}=\mathrm{YWHAB} \text { PE }=1 \mathrm{SV}=3-[1433 \mathrm{~B} \text { HUMAN }]\end{array}$ & 1433B & 8 & 14 & -0.4 & -0.9 & -1.6 & 0.2 & -0.4 & 0.0 \\
\hline P31948 & $\begin{array}{l}\text { Stress-induced-phosphoprotein } 1 \text { OS=Homo sapiens } \\
\text { OX=9606 GN=STIP1 PE=1 SV=1 - [STIP1 HUMAN] }\end{array}$ & STIP1 & 4 & 5 & 0.1 & -2.1 & -0.9 & -1.2 & -0.7 & 0.8 \\
\hline P32969 & $\begin{array}{l}\text { 60S ribosomal protein L9 OS=Homo sapiens OX=9606 } \\
\text { GN=RPL9 PE=1 SV=1 - [RL9 HUMAN] }\end{array}$ & RL9 & 4 & 4 & -0.1 & 0.3 & 1.1 & 1.4 & -1.4 & -1.7 \\
\hline P35232 & $\begin{array}{l}\text { Prohibitin OS=Homo sapiens OX=9606 GN=PHB PE }=1 \\
\text { SV }=1 \text { - [PHB HUMAN] }\end{array}$ & PHB & 10 & 11 & -0.5 & -0.8 & -0.3 & -0.3 & 0.4 & 0.1 \\
\hline P35268 & $\begin{array}{l}\text { 60S ribosomal protein L22 OS=Homo sapiens OX }=9606 \\
\text { GN=RPL22 PE }=1 \mathrm{SV}=2-[\mathrm{RL} 22 \text { HUMAN] }\end{array}$ & RL22 & 2 & 3 & -0.7 & -1.7 & -0.6 & -2.2 & 1.0 & 2.4 \\
\hline P35270 & $\begin{array}{l}\text { Sepiapterin reductase OS=Homo sapiens OX }=9606 \\
\text { GN=SPR PE }=1 \mathrm{SV}=1-[\text { [SRE_HUMAN] }\end{array}$ & SPRE & 5 & 6 & -0.2 & -1.0 & -1.4 & -0.8 & -0.9 & 0.0 \\
\hline
\end{tabular}

Table 2. (continued) 


\begin{tabular}{|c|c|c|c|c|c|c|c|c|c|c|}
\hline P35527 & $\begin{array}{l}\text { Keratin, type I cytoskeletal } 9 \text { OS }=\text { Homo sapiens } \\
\text { OX=9606 GN=KRT9 PE }=1 \mathrm{SV}=3-[\text { K1C9_HUMAN }]\end{array}$ & K1C9 & 19 & 28 & -2.2 & 0.1 & 0.4 & -0.9 & -1.8 & -0.9 \\
\hline P35579 & $\begin{array}{l}\text { Myosin-9 OS=Homo sapiens OX=9606 GN=MYH9 } \\
\text { PE }=1 \mathrm{SV}=4 \text { - [MYH9_HUMAN] }\end{array}$ & MYH9 & 46 & 58 & 1.2 & 0.6 & 1.1 & -0.2 & 0.4 & -0.9 \\
\hline P35908 & $\begin{array}{l}\text { Keratin, type II cytoskeletal } 2 \text { epidermal OS=Homo } \\
\text { sapiens OX=9606 GN=KRT2 PE=1 SV=2 - } \\
\text { [K22E_HUMAN] }\end{array}$ & K22E & 27 & 46 & -2.8 & 0.6 & 0.6 & 1.0 & -1.8 & -2.0 \\
\hline P36578 & $\begin{array}{l}\text { 60S ribosomal protein } \mathrm{L} 4 \text { OS=Homo sapiens OX=9606 } \\
\mathrm{GN}=\mathrm{RPL} 4 \mathrm{PE}=1 \mathrm{SV}=5-[\mathrm{RL} 4 \text { HUMAN] }\end{array}$ & RL4 & 15 & 16 & -0.2 & -1.4 & -0.6 & -1.3 & -0.5 & 0.3 \\
\hline P36957 & $\begin{array}{l}\text { Dihydrolipoyllysine-residue succinyltransferase } \\
\text { component of 2-oxoglutarate dehydrogenase complex, } \\
\text { mitochondrial OS=Homo sapiens OX=9606 GN=DLST } \\
\mathrm{PE}=1 \mathrm{SV}=4-[\mathrm{ODO} 2 \text { HUMAN] }\end{array}$ & ODO2 & 5 & 6 & 0.2 & -1.5 & -1.1 & 1.5 & -1.8 & -0.5 \\
\hline P37802 & $\begin{array}{l}\text { Transgelin-2 OS=Homo sapiens OX=9606 } \\
\text { GN=TAGLN2 PE=1 SV=3 - [TAGL2_HUMAN] }\end{array}$ & TAGL2 & 6 & 27 & -0.9 & -1.2 & 0.0 & 1.2 & -1.2 & -1.8 \\
\hline P37837 & $\begin{array}{l}\text { Transaldolase OS=Homo sapiens OX }=9606 \\
\text { GN=TALDO1 PE }=1 \mathrm{SV}=2-[\text { TALDO_HUMAN] }\end{array}$ & TALDO & 10 & 14 & 1.2 & -0.9 & 1.2 & -2.3 & -1.1 & -1.6 \\
\hline P38159 & $\begin{array}{l}\text { RNA-binding motif protein, } X \text { chromosome OS=Homo } \\
\text { sapiens OX }=9606 \mathrm{GN}=\mathrm{RBMX} \mathrm{PE}=1 \mathrm{SV}=3 \text { - } \\
\text { [RBMX_HUMAN] }\end{array}$ & RBMX & 22 & 26 & 0.1 & 0.4 & 2.1 & -1.5 & -1.9 & -1.7 \\
\hline P38646 & $\begin{array}{l}\text { Stress-70 protein, mitochondrial OS=Homo sapiens } \\
\text { OX=9606 GN=HSPA9 PE }=1 \mathrm{SV}=2 \text { - } \\
\text { [GRP75_HUMAN] }\end{array}$ & GRP75 & 14 & 17 & -0.2 & 0.1 & 2.7 & 2.2 & -2.0 & -0.5 \\
\hline P40227 & $\begin{array}{l}\text { T-complex protein } 1 \text { subunit zeta OS }=\text { Homo sapiens } \\
\text { OX }=9606 \mathrm{GN}=\mathrm{CCT} 6 \mathrm{~A} \text { PE }=1 \mathrm{SV}=3-\left[\mathrm{TCPZ} \_ \text {HUMAN }\right]\end{array}$ & TCPZ & 11 & 15 & -0.3 & -1.2 & -0.3 & -0.4 & -0.9 & 0.3 \\
\hline P40925 & $\begin{array}{l}\text { Malate dehydrogenase, cytoplasmic OS=Homo sapiens } \\
\text { OX=9606 GN=MDH1 PE }=1 \mathrm{SV}=4 \text { - } \\
\text { [MDHC_HUMAN] }\end{array}$ & MDHC & 4 & 5 & 1.1 & -0.3 & 1.6 & -1.2 & -1.4 & -1.8 \\
\hline P40926 & $\begin{array}{l}\text { Malate dehydrogenase, mitochondrial OS=Homo } \\
\text { sapiens OX=9606 GN=MDH2 PE=1 SV=3 - } \\
\text { [MDHM_HUMAN] }\end{array}$ & MDHM & 17 & 26 & 1.7 & -0.7 & 1.3 & -2.3 & -1.6 & -1.8 \\
\hline P42330 & $\begin{array}{l}\text { Aldo-keto reductase family } 1 \text { member } \mathrm{C} 3 \mathrm{OS}=\mathrm{Homo} \\
\text { sapiens OX=9606 GN=AKR1C3 } \mathrm{PE}=1 \mathrm{SV}=4 \text { - } \\
\text { [AK1C3_HUMAN] }\end{array}$ & AK1C3 & 5 & 5 & -0.4 & -0.1 & -0.4 & -1.5 & -0.1 & 0.6 \\
\hline P43307 & $\begin{array}{l}\text { Translocon-associated protein subunit alpha OS=Homo } \\
\text { sapiens OX=9606 GN=SSR1 } \mathrm{PE}=1 \mathrm{SV}=3 \text { - } \\
\text { [SSRA_HUMAN] }\end{array}$ & SSRA & 2 & 3 & -0.3 & -1.2 & 0.2 & -0.3 & -0.6 & -0.5 \\
\hline P45880 & $\begin{array}{l}\text { Voltage-dependent anion-selective channel protein } 2 \\
\text { OS=Homo sapiens OX=9606 GN=VDAC2 } \mathrm{PE}=1 \mathrm{SV}=2 \\
-[\text { VDAC2_HUMAN] }\end{array}$ & VDAC2 & 6 & 7 & 1.0 & -1.3 & 0.0 & -2.0 & -1.0 & -1.7 \\
\hline P46777 & $\begin{array}{l}\text { 60S ribosomal protein L5 OS=Homo sapiens OX }=9606 \\
\mathrm{GN}=\mathrm{RPL} 5 \mathrm{PE}=1 \mathrm{SV}=3-[\mathrm{RL} 5 \text { _HUMAN] }\end{array}$ & RL5 & 11 & 12 & 0.4 & -0.1 & 1.3 & -1.0 & -2.1 & -1.7 \\
\hline P46779 & $\begin{array}{l}\text { 60S ribosomal protein } \mathrm{L} 28 \text { OS=Homo sapiens OX=9606 } \\
\mathrm{GN}=\mathrm{RPL} 28 \mathrm{PE}=1 \mathrm{SV}=3-[\mathrm{RL} 28 \text { HUMAN] }\end{array}$ & RL28 & 6 & 9 & -0.8 & -0.9 & 0.2 & -3.0 & 1.9 & 4.2 \\
\hline P46782 & $\begin{array}{l}\text { 40S ribosomal protein } \mathrm{S} 5 \mathrm{OS}=\text { Homo sapiens } \mathrm{OX}=9606 \\
\mathrm{GN}=\mathrm{RPS} 5 \mathrm{PE}=1 \mathrm{SV}=4-[\mathrm{RS} 5 \text { _HUMAN] }\end{array}$ & RS5 & 8 & 10 & -0.9 & -0.6 & 0.3 & 1.2 & -1.8 & -2.2 \\
\hline P46783 & $\begin{array}{l}\text { 40S ribosomal protein } \mathrm{S} 10 \mathrm{OS}=\text { Homo sapiens } \mathrm{OX}=9606 \\
\mathrm{GN}=\mathrm{RPS} 10 \mathrm{PE}=1 \mathrm{SV}=1-\left[\mathrm{RS} 10 \_ \text {HUMAN] }\right.\end{array}$ & RS10 & 7 & 10 & -0.7 & -2.0 & -0.6 & -2.2 & 1.0 & 2.6 \\
\hline P47755 & $\begin{array}{l}\text { F-actin-capping protein subunit alpha- } 2 \text { OS=Homo } \\
\text { sapiens OX=9606 GN=CAPZA2 } \mathrm{PE}=1 \mathrm{SV}=3 \text { - } \\
\text { [CAZA2_HUMAN] }\end{array}$ & CAZA2 & 4 & 6 & 1.1 & -1.2 & 0.5 & -1.7 & -1.1 & -1.3 \\
\hline P48643 & $\begin{array}{l}\text { T-complex protein } 1 \text { subunit epsilon OS=Homo sapiens } \\
\mathrm{OX}=9606 \mathrm{GN}=\mathrm{CCT} 5 \mathrm{PE}=1 \mathrm{SV}=1 \text { - [TCPE_HUMAN] }\end{array}$ & TCPE & 5 & 8 & 0.0 & -1.7 & -1.0 & -1.1 & -0.6 & 0.5 \\
\hline P49368 & $\begin{array}{l}\text { T-complex protein } 1 \text { subunit gamma OS=Homo sapiens } \\
\text { OX }=9606 \mathrm{GN}=\mathrm{CCCT} 3 \mathrm{PE}=1 \mathrm{SV}=4-[\mathrm{TCPG} \text { HUMAN] }\end{array}$ & TCPG & 13 & 24 & 0.2 & -1.4 & -1.0 & -0.2 & -1.3 & 0.0 \\
\hline P49411 & $\begin{array}{l}\text { Elongation factor Tu, mitochondrial OS=Homo sapiens } \\
\mathrm{OX}=9606 \mathrm{GN}=\mathrm{TUFM} \mathrm{PE}=1 \mathrm{SV}=2 \text { - [EFTU_HUMAN] }\end{array}$ & EFTU & 7 & 9 & 1.1 & -0.6 & 1.1 & -0.9 & -0.9 & 0.5 \\
\hline P49773 & $\begin{array}{l}\text { Histidine triad nucleotide-binding protein } 1 \text { OS=Homo } \\
\text { sapiens OX=9606 GN=HINT1 } \mathrm{PE}=1 \mathrm{SV}=2 \text { - } \\
\text { [HINT1_HUMAN] }\end{array}$ & HINT1 & 1 & 1 & -1.4 & -1.7 & -0.5 & 2.3 & -1.4 & -1.5 \\
\hline P50454 & $\begin{array}{l}\text { Serpin H1 OS=Homo sapiens OX=9606 } \\
\text { GN=SERPINH1 PE=1 SV=2 - [SERPH_HUMAN] }\end{array}$ & SERPH & 11 & 15 & 0.1 & -1.9 & -1.3 & -1.1 & -0.8 & 0.5 \\
\hline P50990 & $\begin{array}{l}\text { T-complex protein } 1 \text { subunit theta OS=Homo sapiens } \\
\text { OX }=9606 \mathrm{GN}=\mathrm{CCT} 8 \mathrm{PE}=1 \mathrm{SV}=4-[\mathrm{TCPQ} \text { HUMAN] }\end{array}$ & TCPQ & 10 & 13 & -0.3 & -1.4 & -0.7 & -1.1 & -0.4 & 0.7 \\
\hline P50991 & $\begin{array}{l}\text { T-complex protein } 1 \text { subunit delta } \mathrm{OS}=\text { Homo sapiens } \\
\text { OX=9606 GN=CCT4 } \mathrm{PE}=1 \mathrm{SV}=4-[\mathrm{TCPD} \text { HUMAN }]\end{array}$ & TCPD & 15 & 18 & -0.7 & -1.3 & -0.7 & 1.1 & -0.7 & -2.1 \\
\hline P50993 & $\begin{array}{l}\text { Sodium/potassium-transporting ATPase subunit alpha-2 } \\
\text { OS=Homo sapiens OX=9606 GN=ATP1A2 PE=1 SV=1 } \\
\text { - [AT1A2_HUMAN] }\end{array}$ & AT1A2 & 15 & 24 & 0.3 & -1.2 & -0.8 & 1.3 & -2.6 & -1.1 \\
\hline P51148 & $\begin{array}{l}\text { Ras-related protein Rab-5C OS }=\text { Homo sapiens } \\
\text { OX=9606 GN=RAB5C PE }=1 \text { SV=2 - } \\
\text { [RAB5C_HUMAN] }\end{array}$ & RAB5C & 7 & 10 & -0.2 & -3.4 & 0.2 & 1.3 & -2.9 & -1.8 \\
\hline P51149 & $\begin{array}{l}\text { Ras-related protein Rab-7a OS=Homo sapiens OX }=9606 \\
\text { GN=RAB7A PE }=1 \text { SV }=1-[\text { RAB7A HUMAN] }\end{array}$ & RAB7A & 4 & 7 & -0.5 & -2.0 & -0.7 & 1.1 & -1.0 & -0.8 \\
\hline P51665 & $\begin{array}{l}\text { 26S proteasome non-ATPase regulatory subunit } 7 \\
\text { OS=Homo sapiens OX=9606 GN=PSMD7 } \mathrm{PE}=1 \mathrm{SV}=2 \\
-[\text { PSMD7_HUMAN] }\end{array}$ & PSMD7 & 3 & 6 & -0.2 & -1.6 & -1.3 & -1.8 & -1.6 & -3.0 \\
\hline P52272 & $\begin{array}{l}\text { Heterogeneous nuclear ribonucleoprotein M OS=Homo } \\
\text { sapiens OX=9606 GN=HNRNPM PE }=1 \mathrm{SV}=3 \text { - } \\
\text { [HNRPM_HUMAN] }\end{array}$ & HNRPM & 39 & 61 & -0.7 & 0.2 & 1.9 & 1.7 & -1.9 & -0.4 \\
\hline P52758 & $\begin{array}{l}\text { 2-iminobutanoate } / 2 \text {-iminopropanoate deaminase } \\
\text { OS=Homo sapiens OX=9606 GN=RIDA PE }=1 \mathrm{SV}=1 \text { - } \\
\text { [RIDA_HUMAN] }\end{array}$ & RIDA & 3 & 5 & -0.2 & -1.1 & 0.6 & 1.9 & -1.2 & -1.5 \\
\hline P52895 & $\begin{array}{l}\text { Aldo-keto reductase family } 1 \text { member } \mathrm{C} 2 \mathrm{OS}=\mathrm{Homo} \\
\text { sapiens OX=9606 GN=AKR1C2 PE=1 SV=3 - } \\
\text { [AK1C2_HUMAN] }\end{array}$ & AK1C2 & 6 & 9 & 0.0 & -1.1 & -0.9 & 0.5 & -1.2 & 0.0 \\
\hline P52907 & $\begin{array}{l}\text { F-actin-capping protein subunit alpha-1 OS=Homo } \\
\text { sapiens OX=9606 GN=CAPZA1 PE }=1 \mathrm{SV}=3 \text { - } \\
\text { [CAZA1_HUMAN] }\end{array}$ & CAZAl & 4 & 6 & 0.0 & -1.5 & -1.1 & 0.0 & -1.6 & -1.1 \\
\hline P53396 & $\begin{array}{l}\text { ATP-citrate synthase OS=Homo sapiens OX }=9606 \\
\mathrm{GN}=\mathrm{ACL} \text { PE }=1 \mathrm{SV}=3-[\mathrm{ACLY} \text { HUMAN] }\end{array}$ & ACLY & 15 & 21 & 2.0 & -1.2 & -2.2 & -0.9 & -0.1 & 0.4 \\
\hline P55072 & $\begin{array}{l}\text { Transitional endoplasmic reticulum ATPase OS=Homo } \\
\text { sapiens OX=9606 GN=VCP PE }=1 \mathrm{SV}=4 \text { - } \\
\text { [TERA_HUMAN] }\end{array}$ & TERA & 21 & 29 & 0.5 & -1.3 & -1.1 & -0.2 & 0.5 & -0.7 \\
\hline P55209 & $\begin{array}{l}\text { Nucleosome assembly protein 1-like } 1 \text { OS=Homo } \\
\text { sapiens OX=9606 GN=NAP1L1 PE=1 SV=1 - } \\
\text { [NP1L1 HUMAN] }\end{array}$ & NP1L1 & 4 & 6 & 0.1 & -2.0 & -1.3 & -2.2 & 0.5 & 1.7 \\
\hline P57735 & $\begin{array}{l}\text { Ras-related protein Rab- } 25 \text { OS=Homo sapiens } \\
\text { OX=9606 GN=RAB25 PE }=1 \mathrm{SV}=2 \text { - } \\
\text { [RAB25_HUMAN] }\end{array}$ & RAB25 & 7 & 17 & 0.4 & 0.3 & 0.6 & 1.0 & -1.2 & -1.1 \\
\hline
\end{tabular}

Table 2. (continued) 


\begin{tabular}{|c|c|c|c|c|c|c|c|c|c|c|}
\hline P60174 & $\begin{array}{l}\text { Triosephosphate isomerase OS=Homo sapiens } \\
\text { OX }=9606 \mathrm{GN}=\mathrm{TPI} 1 \mathrm{PE}=1 \mathrm{SV}=3 \text { - [TPIS HUMAN] }\end{array}$ & TPIS & 10 & 14 & -0.8 & -1.7 & -0.6 & 3.1 & -1.8 & -2.4 \\
\hline P60709 & $\begin{array}{l}\text { Actin, cytoplasmic } 1 \mathrm{OS}=\text { Homo sapiens } \mathrm{OX}=9606 \\
\mathrm{GN}=\mathrm{ACTB} P \mathrm{PE}=1 \mathrm{SV}=1-[\text { ACTB HUMAN] }\end{array}$ & ACTB & 32 & 153 & 1.4 & -1.3 & 0.8 & -2.3 & -0.9 & -0.7 \\
\hline P60842 & $\begin{array}{l}\text { Eukaryotic initiation factor } 4 \mathrm{~A}-\mathrm{I} \mathrm{OS}=\text { Homo sapiens } \\
\text { OX=9606 GN=EIF4A1 } \mathrm{PE}=1 \mathrm{SV}=1 \text { - } \\
\text { [IF4A1_HUMAN] }\end{array}$ & IF4A1 & 14 & 22 & -0.6 & -1.1 & -0.6 & -1.2 & -0.6 & 0.9 \\
\hline P60866 & $\begin{array}{l}\text { 40S ribosomal protein } \mathrm{S} 20 \mathrm{OS}=\text { Homo sapiens } \mathrm{OX}=9606 \\
\mathrm{GN}=\mathrm{RPS} 20 \mathrm{PE}=1 \mathrm{SV}=1-[\mathrm{RS} 20 \mathrm{HUMAN}]\end{array}$ & RS20 & 4 & 5 & -1.4 & -0.8 & 0.5 & 1.2 & -1.0 & -0.8 \\
\hline P61160 & $\begin{array}{l}\text { Actin-related protein } 2 \mathrm{OS}=\text { Homo sapiens OX }=9606 \\
\text { GN=ACTR2 PE }=1 \mathrm{SV}=1-[\mathrm{ARP} 2 \text { HUMAN] }\end{array}$ & ARP2 & 7 & 7 & 0.2 & -2.3 & -1.7 & -1.1 & -0.5 & 0.5 \\
\hline P61247 & $\begin{array}{l}\text { 40S ribosomal protein } \mathrm{S3a} \text { OS=Homo sapiens OX }=9606 \\
\text { GN=RPS3A PE }=1 \mathrm{SV}=2-[\mathrm{RS} 3 \mathrm{~A} \text { _HUMAN] }\end{array}$ & RS3A & 16 & 22 & 1.6 & -0.5 & 2.2 & -1.3 & -2.2 & -1.9 \\
\hline P61353 & $\begin{array}{l}\text { 60S ribosomal protein } \mathrm{L} 27 \text { OS=Homo sapiens } \mathrm{OX}=9606 \\
\text { GN=RPL27 PE }=1 \mathrm{SV}=2-[\mathrm{RL} 27 \text { HUMAN] }\end{array}$ & RL27 & 5 & 5 & -0.6 & -2.3 & -0.9 & -4.3 & 2.7 & 3.8 \\
\hline P61604 & $\begin{array}{l}10 \mathrm{kDa} \text { heat shock protein, mitochondrial OS=Homo } \\
\text { sapiens OX=9606 GN=HSPE1 PE }=1 \mathrm{SV}=2 \text { - } \\
\text { [CH10_HUMAN] }\end{array}$ & CH10 & 7 & 13 & -1.1 & -1.3 & 0.5 & 1.6 & -1.0 & -0.9 \\
\hline P61978 & $\begin{array}{l}\text { Heterogeneous nuclear ribonucleoprotein } \mathrm{K} \text { OS=Homo } \\
\text { sapiens OX=9606 GN=HNRNPK PE }=1 \mathrm{SV}=1 \text { - } \\
\text { [HNRPK_HUMAN] }\end{array}$ & HNRPK & 17 & 28 & 0.2 & -2.1 & -1.5 & -0.5 & -1.0 & 0.4 \\
\hline P61981 & $\begin{array}{l}\text { 14-3-3 protein gamma OS=Homo sapiens OX }=9606 \\
\text { GN=YWHAG } \mathrm{PE}=1 \mathrm{SV}=2-\left[1433 \mathrm{G} \_\mathrm{HUMAN}\right]\end{array}$ & $1433 \mathrm{G}$ & 6 & 7 & -0.3 & -1.2 & -1.4 & -1.1 & 0.9 & 0.7 \\
\hline P62081 & $\begin{array}{l}\text { 40S ribosomal protein } \mathrm{S} 7 \mathrm{OS}=\text { Homo sapiens } \mathrm{OX}=9606 \\
\mathrm{GN}=\mathrm{RPS} 7 \mathrm{PE}=1 \mathrm{SV}=1-[\mathrm{RS} 7 \text { HUMAN] }\end{array}$ & RS7 & 8 & 13 & -1.4 & -1.3 & 0.1 & 2.0 & -1.3 & -1.7 \\
\hline P62244 & $\begin{array}{l}\text { 40S ribosomal protein } \mathrm{S} 15 \mathrm{a} \mathrm{OS}=\text { =Homo sapiens } \\
\text { OX=9606 GN=RPS15A PE=1 SV=2 - } \\
\text { [RS15A_HUMAN] }\end{array}$ & RS15A & 4 & 4 & -0.4 & -2.8 & -1.2 & -3.2 & 1.7 & 2.7 \\
\hline P62249 & $\begin{array}{l}\text { 40S ribosomal protein } \mathrm{S} 16 \mathrm{OS}=\text { Homo sapiens } \mathrm{OX}=9606 \\
\mathrm{GN}=\mathrm{RPS} 16 \mathrm{PE}=1 \mathrm{SV}=2-[\mathrm{RS} 16 \text { HUMAN] }\end{array}$ & RS16 & 7 & 12 & -0.7 & -1.0 & 0.0 & 0.9 & -1.1 & -0.3 \\
\hline P62258 & $\begin{array}{l}\text { 14-3-3 protein epsilon } \mathrm{OS}=\text { Homo sapiens } \mathrm{OX}=9606 \\
\mathrm{GN}=\mathrm{YWHAE} \mathrm{PE}=1 \mathrm{SV}=1-[1433 \mathrm{E} \text { HUMAN }]\end{array}$ & $1433 \mathrm{E}$ & 9 & 16 & 0.0 & -0.8 & -1.0 & -1.4 & -1.4 & -1.5 \\
\hline P62266 & $\begin{array}{l}\text { 40S ribosomal protein } \mathrm{S} 23 \mathrm{OS}=\text { Homo sapiens } \mathrm{OX}=9606 \\
\mathrm{GN}=\mathrm{RPS} 23 \mathrm{PE}=1 \mathrm{SV}=3-[\mathrm{RS} 23 \text { HUMAN] }\end{array}$ & RS23 & 5 & 9 & -0.8 & -1.0 & 0.4 & 1.2 & -1.4 & -1.9 \\
\hline P62269 & $\begin{array}{l}\text { 40S ribosomal protein } \mathrm{S} 18 \mathrm{OS}=\text { Homo sapiens } \mathrm{OX}=9606 \\
\mathrm{GN}=\mathrm{RPS} 18 \mathrm{PE}=1 \mathrm{SV}=3-\left[\mathrm{RS} 18 \_ \text {HUMAN] }\right.\end{array}$ & RS18 & 4 & 6 & -0.6 & -1.3 & -0.4 & -2.7 & 1.2 & 2.9 \\
\hline P62277 & $\begin{array}{l}\text { 40S ribosomal protein } \mathrm{S} 13 \text { OS=Homo sapiens } \mathrm{OX}=9606 \\
\mathrm{GN}=\mathrm{RPS} 13 \mathrm{PE}=1 \mathrm{SV}=2-[\mathrm{RS} 13 \text { HUMAN] }\end{array}$ & RS13 & 8 & 10 & -1.0 & -1.0 & 0.6 & -3.0 & 1.1 & 3.1 \\
\hline P62424 & $\begin{array}{l}\text { 60S ribosomal protein L7a OS=Homo sapiens OX=9606 } \\
\text { GN }=\text { RPL7A PE }=1 \mathrm{SV}=2-[\mathrm{RL7A} \text { HUMAN }]\end{array}$ & RL7A & 6 & 6 & -0.4 & -1.8 & -0.8 & 0.6 & -0.1 & 0.0 \\
\hline P62701 & $\begin{array}{l}\text { 40S ribosomal protein S4, X isoform OS=Homo sapiens } \\
\text { OX }=9606 \mathrm{GN}=\mathrm{RPS} 4 \mathrm{X} \text { PE }=1 \mathrm{SV}=2-[\mathrm{RS} 4 \mathrm{X} \text { HUMAN }]\end{array}$ & RS4X & 4 & 4 & -0.1 & -1.1 & -1.1 & 2.4 & -1.9 & -3.1 \\
\hline P62805 & $\begin{array}{l}\text { Histone H4 OS=Homo sapiens OX=9606 } \\
\text { GN=HIST1H4A PE }=1 \mathrm{SV}=2-[\mathrm{H} 4 \text { HUMAN] }\end{array}$ & $\mathrm{H} 4$ & 11 & 47 & -1.6 & -1.0 & 0.5 & 2.8 & -3.1 & -3.8 \\
\hline P62826 & $\begin{array}{l}\text { GTP-binding nuclear protein Ran OS=Homo sapiens } \\
\text { OX=9606 GN=RAN PE=1 SV=3 - [RAN_HUMAN] }\end{array}$ & RAN & 8 & 12 & -1.4 & -1.5 & -0.2 & 2.9 & -2.0 & -2.5 \\
\hline P62851 & $\begin{array}{l}\text { 40S ribosomal protein } \mathrm{S} 25 \mathrm{OS}=\text { Homo sapiens OX=9606 } \\
\text { GN=RPS25 PE=1 SV=1 - [RS25_HUMAN] }\end{array}$ & RS25 & 4 & 6 & -1.6 & -1.0 & 0.7 & 2.9 & -2.1 & -2.2 \\
\hline P62857 & $\begin{array}{l}\text { 40S ribosomal protein } \mathrm{S} 28 \text { OS=Homo sapiens OX=9606 } \\
\text { GN }=\mathrm{RPS} 28 \mathrm{PE}=1 \mathrm{SV}=1 \text { - [RS28_HUMAN] }\end{array}$ & RS28 & 5 & 14 & -2.8 & -1.5 & 0.3 & -3.1 & 2.0 & 3.9 \\
\hline P62899 & $\begin{array}{l}\text { 60S ribosomal protein } \mathrm{L} 31 \mathrm{OS}=\mathrm{H} \text { omo sapiens } \mathrm{OX}=9606 \\
\mathrm{GN}=\mathrm{RPL} 31 \mathrm{PE}=1 \mathrm{SV}=1-\left[\mathrm{RL} 31 \_ \text {HUMAN] }\right.\end{array}$ & RL31 & 3 & 4 & -0.8 & -1.5 & -0.4 & -2.8 & 1.1 & 2.5 \\
\hline P62910 & $\begin{array}{l}\text { 60S ribosomal protein } \mathrm{L} 32 \mathrm{OS}=\mathrm{Homo} \text { sapiens } \mathrm{OX}=9606 \\
\mathrm{GN}=\mathrm{RPL} 32 \mathrm{PE}=1 \mathrm{SV}=2-[\mathrm{RL} 32 \text { HUMAN] }\end{array}$ & RL32 & 4 & 5 & -0.9 & -0.9 & 0.9 & 1.3 & -1.1 & -1.8 \\
\hline P62917 & $\begin{array}{l}\text { 60S ribosomal protein } \mathrm{L} 8 \mathrm{OS}=\text { Homo sapiens } \mathrm{OX}=9606 \\
\mathrm{GN}=\mathrm{RPL} 8 \mathrm{PE}=1 \mathrm{SV}=2-[\mathrm{RL} 8 \text { HUMAN] }\end{array}$ & RL8 & 12 & 13 & 1.0 & -0.5 & 1.6 & -1.1 & -1.5 & -1.8 \\
\hline P62937 & $\begin{array}{l}\text { Peptidyl-prolyl cis-trans isomerase A OS=Homo sapiens } \\
\text { OX=9606 GN=PPIA PE }=1 \text { SV=2 - [PPIA_HUMAN] }\end{array}$ & PPIA & 10 & 22 & -1.4 & -1.3 & 0.4 & 1.9 & -1.5 & -2.7 \\
\hline P62979 & $\begin{array}{l}\text { Ubiquitin-40S ribosomal protein } \mathrm{S} 27 \mathrm{a} \text { OS=Homo } \\
\text { sapiens OX=9606 GN=RPS27A PE=1 SV=2 - } \\
\text { [RS27A_HUMAN] }\end{array}$ & RS27A & 8 & 19 & -1.5 & -1.7 & 0.5 & 2.2 & -2.3 & -2.7 \\
\hline P62995 & $\begin{array}{l}\text { Transformer-2 protein homolog beta OS=Homo sapiens } \\
\text { OX=9606 GN=TRA2B PE }=1 \mathrm{SV}=1 \text { - } \\
\text { [TRA2B_HUMAN] }\end{array}$ & TRA2B & 11 & 16 & 0.9 & -1.1 & 0.9 & 0.2 & -1.9 & -0.8 \\
\hline P63104 & $\begin{array}{l}\text { 14-3-3 protein zeta/delta OS=Homo sapiens OX }=9606 \\
\text { GN=YWHAZ PE }=1 \mathrm{SV}=1-[1433 Z \text { HUMAN] }\end{array}$ & $1433 Z$ & 14 & 36 & -0.9 & -1.7 & -0.3 & -0.4 & 0.2 & 0.3 \\
\hline P63244 & $\begin{array}{l}\text { Receptor of activated protein C kinase } 1 \mathrm{OS}=\text { Homo } \\
\text { sapiens OX=9606 GN=RACK1 PE=1 SV=3 - } \\
\text { [RACK1_HUMAN] }\end{array}$ & RACK1 & 13 & 19 & -1.1 & -1.2 & -0.4 & -2.2 & -2.2 & -1.3 \\
\hline P68104 & $\begin{array}{l}\text { Elongation factor } 1 \text {-alpha } 1 \mathrm{OS}=\text { Homo sapiens } \\
\text { OX=9606 GN=EEF1A1 } \mathrm{PE}=1 \mathrm{SV}=1 \text { - } \\
\text { [EF1A1 HUMAN] }\end{array}$ & EF1A1 & 16 & 31 & -0.9 & -1.7 & -1.0 & 1.3 & -0.9 & -2.5 \\
\hline P68133 & $\begin{array}{l}\text { Actin, alpha skeletal muscle OS=Homo sapiens } \\
\text { OX=9606 GN=ACTA1 PE }=1 \mathrm{SV}=1 \text { - } \\
\text { [ACTS_HUMAN] }\end{array}$ & ACTS & 16 & 61 & 0.9 & -1.7 & -2.3 & -2.4 & -2.1 & -1.4 \\
\hline P68371 & $\begin{array}{l}\text { Tubulin beta-4B chain OS=Homo sapiens OX }=9606 \\
\text { GN=TUBB4B PE }=1 \mathrm{SV}=1-[\mathrm{TBB} 4 \mathrm{~B} \text { HUMMAN] }\end{array}$ & TBB4B & 20 & 44 & -0.3 & -1.3 & -0.4 & 0.9 & -0.6 & -1.2 \\
\hline P68431 & $\begin{array}{l}\text { Histone H3.1 OS=Homo sapiens OX=9606 } \\
\text { GN=HIST1H3A PE=1 SV=2-[H31_HUMAN }]\end{array}$ & $\mathrm{H} 31$ & 8 & 13 & 0.2 & 1.2 & 1.7 & 2.5 & -1.9 & -2.4 \\
\hline P78371 & $\begin{array}{l}\text { T-complex protein } 1 \text { subunit beta } \mathrm{OS}=\text { Homo sapiens } \\
\text { OX=9606 } \mathrm{GN}=\mathrm{CCT} 2 \mathrm{PE}=1 \mathrm{SV}=4-\text { - [TCPB_HUMAN] }\end{array}$ & TCPB & 17 & 19 & -0.5 & -1.6 & -0.9 & 1.8 & -0.3 & -2.4 \\
\hline P81605 & $\begin{array}{l}\text { Dermcidin OS=Homo sapiens OX }=9606 \mathrm{GN}=\mathrm{DCD} \\
\mathrm{PE}=1 \mathrm{SV}=2-[\mathrm{DCD} \text { HUMAN }]\end{array}$ & DCD & 4 & 5 & -1.4 & 0.3 & 0.7 & 1.6 & -2.4 & -2.7 \\
\hline Q00534 & $\begin{array}{l}\text { Cyclin-dependent kinase } 6 \text { OS=Homo sapiens OX=9606 } \\
\text { GN=CDK6 PE }=1 \mathrm{SV}=1-[\mathrm{CDK} 6 \text { HUMAN] }\end{array}$ & CDK6 & 8 & 11 & -0.1 & -0.9 & -1.1 & -1.1 & -1.0 & -1.3 \\
\hline Q00610 & $\begin{array}{l}\text { Clathrin heavy chain } 1 \mathrm{OS}=\text { Homo sapiens OX }=9606 \\
\text { GN=CLTC PE }=1 \mathrm{SV}=5-\left[\mathrm{CLH} 1 \_ \text {HUMAN] }\right.\end{array}$ & CLH1 & 26 & 29 & 0.3 & -1.4 & -1.2 & -2.1 & 1.0 & 2.8 \\
\hline Q00839 & $\begin{array}{l}\text { Heterogeneous nuclear ribonucleoprotein } \mathrm{U} \text { OS=Homo } \\
\text { sapiens OX=9606 GN=HNRNPU PE }=1 \mathrm{SV}=6 \text { - } \\
\text { [HNRPU_HUMAN] }\end{array}$ & HNRPU & 14 & 15 & 0.0 & -1.0 & -0.7 & 1.3 & -2.8 & -1.0 \\
\hline Q02878 & $\begin{array}{l}\text { 60S ribosomal protein } \mathrm{L} 6 \mathrm{OS}=\text { Homo sapiens } \mathrm{OX}=9606 \\
\mathrm{GN}=\mathrm{RPL} 6 \mathrm{PE}=1 \mathrm{SV}=3-\left[\mathrm{RL} 6 \_ \text {HUMAN] }\right.\end{array}$ & RL6 & 5 & 7 & -0.2 & -0.9 & -1.9 & -3.5 & 2.0 & 1.3 \\
\hline Q03252 & $\begin{array}{l}\text { Lamin-B2 OS=Homo sapiens OX=9606 GN=LMNB2 } \\
\text { PE=1 SV=4 - [LMNB2_HUMAN] }\end{array}$ & LMNB2 & 21 & 26 & -0.2 & -1.7 & -0.8 & 2.1 & -0.5 & -2.6 \\
\hline
\end{tabular}

Table 2. (continued) 


\begin{tabular}{|c|c|c|c|c|c|c|c|c|c|c|}
\hline Q04828 & $\begin{array}{l}\text { Aldo-keto reductase family } 1 \text { member } \mathrm{C} 1 \mathrm{OS}=\text { Homo } \\
\text { sapiens OX=9606 GN=AKR1C1 PE=1 SV=1 - } \\
\text { [AK1C1_HUMAN] }\end{array}$ & $\mathrm{AK} 1 \mathrm{Cl}$ & 5 & 7 & -0.1 & -1.1 & -0.8 & -1.3 & -1.2 & -1.0 \\
\hline Q04917 & $\begin{array}{l}\text { 14-3-3 protein eta OS=Homo sapiens OX=9606 } \\
\text { GN }=\text { YWHAH PE }=1 \mathrm{SV}=4-\left[1433 \mathrm{~F} \_\mathrm{HUMAN}\right]\end{array}$ & $1433 \mathrm{~F}$ & 6 & 6 & -1.5 & -0.3 & -1.7 & -0.7 & -0.6 & 0.2 \\
\hline Q06830 & $\begin{array}{l}\text { Peroxiredoxin-1 OS=Homo sapiens OX=9606 } \\
\text { GN=PRDX1 PE=1 SV=1 - [PRDX1_HUMAN] }\end{array}$ & PRDX1 & 12 & 30 & -1.3 & -1.3 & -0.2 & 1.4 & -1.7 & -1.9 \\
\hline Q07065 & $\begin{array}{l}\text { Cytoskeleton-associated protein } 4 \mathrm{OS}=\text { Homo sapiens } \\
\text { OX=9606 GN=CKAP4 } \mathrm{PE}=1 \mathrm{SV}=2 \text { - } \\
\text { [CKAP4_HUMAN] }\end{array}$ & CKAP4 & 5 & 6 & 0.1 & -2.4 & -1.1 & -1.7 & 0.3 & 1.4 \\
\hline Q07955 & $\begin{array}{l}\text { Serine/arginine-rich splicing factor } 1 \text { OS=Homo sapiens } \\
\text { OX=9606 GN=SRSF1 PE }=1 \mathrm{SV}=2 \text { - [SRSF1_HUMAN] }\end{array}$ & SRSF 1 & 15 & 22 & -0.7 & -1.6 & -0.7 & -1.5 & -1.0 & -1.4 \\
\hline Q08257 & $\begin{array}{l}\text { Quinone oxidoreductase OS=Homo sapiens OX }=9606 \\
\text { GN=CRYZ PE }=1 \mathrm{SV}=1-[\mathrm{QOR} \text { HUMAN] }\end{array}$ & QOR & 7 & 13 & -0.3 & -1.1 & -1.8 & -1.4 & -1.0 & -1.0 \\
\hline Q13162 & $\begin{array}{l}\text { Peroxiredoxin-4 OS=Homo sapiens OX=9606 } \\
\text { GN=PRDX4 PE=1 SV=1 - [PRDX4 HUMAN] }\end{array}$ & PRDX4 & 5 & 12 & -0.8 & -0.6 & -0.6 & 1.2 & -1.2 & -1.4 \\
\hline Q13442 & $\begin{array}{l}28 \mathrm{kDa} \text { heat- and acid-stable phosphoprotein OS=Homo } \\
\text { sapiens OX=9606 GN=PDAP1 PE }=1 \mathrm{SV}=1 \text { - } \\
\text { [HAP28_HUMAN] }\end{array}$ & HAP28 & 4 & 4 & -0.5 & 0.2 & 0.6 & 0.7 & -1.1 & -0.7 \\
\hline Q14315 & $\begin{array}{l}\text { Filamin-C OS }=\text { Homo sapiens OX }=9606 \mathrm{GN}=\mathrm{FLNC} \\
\mathrm{PE}=1 \mathrm{SV}=3-\left[\mathrm{FLNC} \_ \text {HUMAN] }\right.\end{array}$ & FLNC & 34 & 45 & -1.5 & 0.1 & 0.6 & 1.6 & -2.8 & -1.3 \\
\hline Q14376 & $\begin{array}{l}\text { UDP-glucose 4-epimerase OS=Homo sapiens OX=9606 } \\
\text { GN=GALE PE }=1 \text { SV }=2-[\text { GALE_HUMAN] }\end{array}$ & GALE & 2 & 2 & 0.0 & -1.6 & -1.0 & 0.0 & -0.9 & -0.1 \\
\hline Q14847 & $\begin{array}{l}\text { LIM and SH3 domain protein } 1 \text { OS }=\text { Homo sapiens } \\
\text { OX=9606 GN=LASP1 PE=1 SV=2 - } \\
\text { [LASP1_HUMAN] }\end{array}$ & LASP1 & 8 & 8 & 0.2 & -1.6 & -1.5 & 1.3 & -0.4 & -1.6 \\
\hline Q14974 & $\begin{array}{l}\text { Importin subunit beta-1 OS=Homo sapiens OX }=9606 \\
\mathrm{GN}=\mathrm{KPNB} 1 \mathrm{PE}=1 \mathrm{SV}=2-[\mathrm{IMB} 1 \text { HUMAN] }\end{array}$ & IMB1 & 10 & 13 & -1.4 & -0.5 & 0.4 & -0.1 & 0.3 & -0.2 \\
\hline Q15008 & $\begin{array}{l}\text { 26S proteasome non-ATPase regulatory subunit } 6 \\
\text { OS=Homo sapiens OX=9606 } \mathrm{GN}=\mathrm{PSMD} 6 \mathrm{PE}=1 \mathrm{SV}=1 \\
\text { - [PSMD6_HUMAN] }\end{array}$ & PSMD6 & 8 & 15 & -0.1 & -1.6 & -0.7 & -0.7 & -1.5 & -1.4 \\
\hline Q15084 & $\begin{array}{l}\text { Protein disulfide-isomerase } \mathrm{A} 6 \mathrm{OS}=\text { Homo sapiens } \\
\text { OX }=9606 \mathrm{GN}=\mathrm{PDIA} 6 \mathrm{PE}=1 \mathrm{SV}=1-\text { - [PDIA6_HUMAN] }\end{array}$ & PDIA6 & 10 & 16 & -0.4 & -0.1 & 1.5 & -2.4 & 0.5 & 1.2 \\
\hline Q15181 & $\begin{array}{l}\text { Inorganic pyrophosphatase OS=Homo sapiens } \\
\text { OX }=9606 \mathrm{GN}=\text { PPA1 PE }=1 \mathrm{SV}=2-[\text { [IPYR_HUMAN] }\end{array}$ & IPYR & 5 & 8 & 1.2 & -0.8 & 1.3 & -1.2 & -2.0 & -2.3 \\
\hline Q15233 & $\begin{array}{l}\text { Non-POU domain-containing octamer-binding protein } \\
\text { OS=Homo sapiens OX }=9606 \mathrm{GN}=\mathrm{NONO} \mathrm{PE}=1 \mathrm{SV}=4 \text { - } \\
{[\mathrm{NONO} \text { HUMAN] }}\end{array}$ & NONO & 11 & 14 & 0.0 & -0.3 & 2.6 & -0.8 & -1.0 & 0.2 \\
\hline Q15366 & $\begin{array}{l}\text { Poly(rC)-binding protein } 2 \text { OS=Homo sapiens OX }=9606 \\
\text { GN=PCBP2 PE= }=1 \text { SV }=1 \text { - [PCBP2 HUMAN] }\end{array}$ & PCBP2 & 7 & 9 & -0.5 & -1.4 & -1.3 & -2.7 & -1.3 & -1.2 \\
\hline Q15417 & $\begin{array}{l}\text { Calponin-3 OS=Homo sapiens OX=9606 GN=CNN3 } \\
P E=1 \text { SV }=1-[C N N 3 \text { HUMAN }]\end{array}$ & CNN3 & 9 & 11 & 0.7 & -0.5 & 1.2 & -1.4 & -1.2 & -1.3 \\
\hline Q5VTE0 & $\begin{array}{l}\text { Putative elongation factor 1-alpha-like } 3 \mathrm{OS}=\text { Homo } \\
\text { sapiens OX=9606 GN=EEF1A1P5 } \mathrm{PE}=5 \mathrm{SV}=1 \text { - } \\
\text { [EF1A3_HUMAN] }\end{array}$ & EF1A3 & 14 & 26 & 0.1 & -2.6 & -0.8 & -1.9 & -0.3 & 1.1 \\
\hline Q6PI78 & $\begin{array}{l}\text { Transmembrane protein } 65 \mathrm{OS}=\text { Homo sapiens } \\
\text { OX=9606 GN=TMEM } 65 \mathrm{PE}=1 \mathrm{SV}=2 \text { - } \\
\text { [TMM65_HUMAN] }\end{array}$ & TMM65 & 1 & 1 & 0.2 & -1.6 & -1.2 & -0.3 & -1.1 & 0.2 \\
\hline Q6ZRQ5 & $\begin{array}{l}\text { Protein MMS22-like OS=Homo sapiens OX=9606 } \\
\text { GN=MMS22L PE=1 SV=3 - [MMS22_HUMAN] }\end{array}$ & MMS22 & 15 & 25 & 1.2 & -0.3 & 3.1 & -0.1 & 0.1 & 0.0 \\
\hline Q86XK2 & $\begin{array}{l}\text { F-box only protein } 11 \text { OS=Homo sapiens OX=9606 } \\
\text { GN=FBXO11 PE=1 SV=3 - [FBX11_HUMAN] }\end{array}$ & FBX11 & 8 & 13 & 0.9 & -3.0 & -0.6 & -0.1 & 0.1 & 0.0 \\
\hline Q8IYB7 & $\begin{array}{l}\text { DIS3-like exonuclease } 2 \text { OS=Homo sapiens OX }=9606 \\
\text { GN=DIS3L2 PE }=1 \mathrm{SV}=4-[\mathrm{DI} 3 \mathrm{~L} 2 \text { HUMAN] }\end{array}$ & DI3L2 & 7 & 9 & -0.6 & -1.2 & -0.3 & 0.3 & -3.9 & 0.7 \\
\hline Q8N257 & $\begin{array}{l}\text { Histone } \mathrm{H} 2 \mathrm{~B} \text { type } 3-\mathrm{B} \mathrm{OS}=\mathrm{Homo} \text { sapiens } \mathrm{OX}=9606 \\
\mathrm{GN}=\mathrm{HIST} 3 \mathrm{H} 2 \mathrm{BB} \mathrm{PE}=1 \mathrm{SV}=3-[\mathrm{H} 2 \mathrm{~B} 3 \mathrm{~B} \text { _HUMAN] }\end{array}$ & H2B3B & 10 & 49 & -1.2 & -0.8 & 0.4 & 1.0 & -1.0 & -1.7 \\
\hline Q8NBS9 & $\begin{array}{l}\text { Thioredoxin domain-containing protein } 5 \mathrm{OS}=\text { Homo } \\
\text { sapiens OX=9606 GN=TXNDC5 } \mathrm{PE}=1 \mathrm{SV}=2 \text { - } \\
\text { [TXND5_HUMAN] }\end{array}$ & TXND5 & 5 & 7 & 0.1 & -1.5 & -1.1 & -0.9 & -1.0 & 0.4 \\
\hline Q969Z0 & $\begin{array}{l}\text { FAST kinase domain-containing protein } 4 \mathrm{OS}=\mathrm{Homo} \\
\text { sapiens OX=9606 GN=TBRG4 } \mathrm{PE}=1 \mathrm{SV}=1 \text { - } \\
\text { [FAKD4_HUMAN] }\end{array}$ & FAKD4 & 10 & 13 & 0.0 & 0.2 & 1.8 & -0.1 & -0.2 & -0.2 \\
\hline Q96C19 & $\begin{array}{l}\text { EF-hand domain-containing protein D2 OS=Homo } \\
\text { sapiens OX=9606 GN=EFHD2 } \mathrm{PE}=1 \mathrm{SV}=1 \text { - } \\
\text { [EFHD2_HUMAN] }\end{array}$ & EFHD2 & 7 & 8 & -0.1 & -1.0 & -1.1 & -1.5 & -0.9 & -0.8 \\
\hline Q99497 & $\begin{array}{l}\text { Protein/nucleic acid deglycase DJ-1 OS=Homo sapiens } \\
\text { OX=9606 GN=PARK7 PE }=1 \mathrm{SV}=2 \text { - } \\
\text { [PARK7_HUMAN] }\end{array}$ & PARK7 & 4 & 14 & -0.6 & -0.9 & -0.1 & 2.1 & -1.4 & -1.6 \\
\hline Q99623 & $\begin{array}{l}\text { Prohibitin- } 2 \text { OS=Homo sapiens OX=9606 GN=PHB2 } \\
\text { PE }=1 \text { SV }=2-[\text { PHB2 HUMAN }]\end{array}$ & PHB2 & 11 & 16 & -0.4 & -2.0 & -0.5 & -1.7 & -1.3 & -1.2 \\
\hline Q99714 & $\begin{array}{l}\text { 3-hydroxyacyl-CoA dehydrogenase type-2 OS=Homo } \\
\text { sapiens OX=9606 GN=HSD17B10 PE=1 SV=3- } \\
{[\text { HCD2_HUMAN] }}\end{array}$ & HCD2 & 5 & 7 & -0.3 & -1.3 & -0.8 & 0.8 & -1.0 & -0.9 \\
\hline Q99729 & $\begin{array}{l}\text { Heterogeneous nuclear ribonucleoprotein } \mathrm{A} / \mathrm{B} \\
\mathrm{OS}=\text { Homo sapiens OX=9606 GN=HNRNPAB PE=1 } \\
\mathrm{SV}=2-[\text { ROAA_HUMAN] }\end{array}$ & ROAA & 4 & 4 & 0.2 & -1.9 & -0.9 & 0.0 & -1.3 & 0.2 \\
\hline Q99832 & $\begin{array}{l}\text { T-complex protein } 1 \text { subunit eta OS=Homo sapiens } \\
\text { OX=9606 GN=CCT7 PE }=1 \mathrm{SV}=2-[\text { [TCPH_HUMAN }]\end{array}$ & $\mathrm{TCPH}$ & 11 & 15 & 0.1 & -1.3 & -0.6 & -0.6 & -1.0 & 0.2 \\
\hline Q9BPU6 & $\begin{array}{l}\text { Dihydropyrimidinase-related protein } 5 \mathrm{OS}=\mathrm{Homo} \\
\text { sapiens OX=9606 GN=DPYSL5 PE=1 SV=1 - } \\
\text { [DPYL5_HUMAN] }\end{array}$ & DPYL5 & 3 & 6 & -0.8 & -0.9 & 0.4 & 1.4 & -1.2 & -1.8 \\
\hline Q9BQE3 & $\begin{array}{l}\text { Tubulin alpha-1C chain OS=Homo sapiens OX }=9606 \\
\text { GN=TUBA1C PE }=1 \mathrm{SV}=1-[\mathrm{TBA} 1 \mathrm{H} \text { HUMAN] }\end{array}$ & TBA1C & 21 & 41 & -0.5 & -1.5 & -0.5 & -0.6 & -1.2 & 0.4 \\
\hline Q9BTM1 & $\begin{array}{l}\text { Histone } \mathrm{H} 2 \mathrm{~A} . J \mathrm{OS}=\mathrm{Homo} \text { sapiens OX }=9606 \\
\mathrm{GN}=\mathrm{H} 2 \mathrm{AFJ} \mathrm{PE}=1 \mathrm{SV}=1-[\mathrm{H} 2 \mathrm{AJ} \text { HUMAN] }\end{array}$ & H2AJ & 6 & 16 & -1.4 & -1.2 & -0.2 & 1.1 & -1.1 & -1.7 \\
\hline$\overline{\mathrm{Q} 9 \mathrm{H} 0 \mathrm{C} 2}$ & $\begin{array}{l}\text { ADP/ATP translocase } 4 \text { OS }=\text { Homo sapiens OX }=9606 \\
\text { GN=SLC25A31 PE }=2 \mathrm{SV}=1-[\text { ADT4_HUMAN] }\end{array}$ & ADT4 & 10 & 12 & 0.2 & 0.3 & 1.6 & -0.7 & 1.0 & -0.5 \\
\hline Q9H0E2 & $\begin{array}{l}\text { Toll-interacting protein OS=Homo sapiens OX }=9606 \\
\text { GN }=\text { TOLLLIP PE }=1 \mathrm{SV}=1-[\text { [TOLIP_HUMAN] }\end{array}$ & TOLIP & 3 & 3 & -0.2 & -0.4 & 1.2 & 0.6 & -0.7 & -0.2 \\
\hline Q9NR45 & $\begin{array}{l}\text { Sialic acid synthase OS }=\text { Homo sapiens } O X=9606 \\
\text { GN }=\text { NANS PE }=1 \text { SV }=2-[\text { SIAS_HUMAN] }\end{array}$ & SIAS & 8 & 10 & 1.0 & 0.1 & 1.6 & -1.5 & -0.9 & -0.9 \\
\hline Q9NRX3 & $\begin{array}{l}\text { NADH dehydrogenase [ubiquinone] } 1 \text { alpha subcomplex } \\
\text { subunit 4-like } 2 \text { OS=Homo sapiens OX=9606 } \\
\text { GN=NDUFA4L2 PE=3 SV=1 - [NUA4L HUMAN] }\end{array}$ & NDUFA4L2 & 2 & 2 & -0.1 & 0.1 & 0.0 & 0.4 & -1.7 & -0.9 \\
\hline Q9NSD9 & $\begin{array}{l}\text { Phenylalanine--tRNA ligase beta subunit } \mathrm{OS}=\text { Homo } \\
\text { sapiens OX=9606 GN=FARSB PE }=1 \mathrm{SV}=3 \text { - } \\
\text { [SYFB_HUMAN] }\end{array}$ & SYFB & 4 & 4 & 0.3 & -1.4 & -1.1 & 0.2 & -1.7 & -0.2 \\
\hline
\end{tabular}

Table 2. (continued) 


\begin{tabular}{|c|c|c|c|c|c|c|c|c|c|c|}
\hline Q9P219 & $\begin{array}{l}\text { Protein Daple OS }=\text { Homo sapiens OX }=9606 \\
\mathrm{GN}=\mathrm{CCDC} 88 \mathrm{C} \text { PE }=1 \mathrm{SV}=3 \text { - [DAPLE HUMAN] }\end{array}$ & DAPLE & 36 & 47 & -0.1 & 0.8 & 0.8 & 0.1 & -1.5 & -0.2 \\
\hline Q9UBQ5 & $\begin{array}{l}\text { Eukaryotic translation initiation factor } 3 \text { subunit } \mathrm{K} \\
\text { OS=Homo sapiens } \mathrm{OX}=9606 \mathrm{GN}=\mathrm{EIF} 3 \mathrm{~K} \mathrm{PE}=1 \mathrm{SV}=1 \text { - } \\
\text { [EIF3K HUMAN] }\end{array}$ & EIF3K & 3 & 7 & -0.7 & -0.8 & -0.2 & 0.1 & -1.4 & 0.6 \\
\hline Q9UHV9 & $\begin{array}{l}\text { Prefoldin subunit } 2 \text { OS }=\text { Homo sapiens } \mathrm{OX}=9606 \\
\mathrm{GN}=\mathrm{PFDN} 2 \mathrm{PE}=1 \mathrm{SV}=1-\left[\mathrm{PFD} 2 \_ \text {HUMAN }\right]\end{array}$ & PFD2 & 3 & 4 & 0.2 & -0.3 & 0.3 & 0.5 & -0.8 & -0.4 \\
\hline Q9UL46 & $\begin{array}{l}\text { Proteasome activator complex subunit } 2 \mathrm{OS}=\text { Homo } \\
\text { sapiens OX=9606 GN=PSME2 } \mathrm{PE}=1 \mathrm{SV}=4 \text { - } \\
{[\mathrm{PSME} 2 \text { HUMAN] }}\end{array}$ & PSME2 & 7 & 14 & 1.0 & -0.9 & 0.9 & -1.4 & -1.3 & -1.1 \\
\hline Q9ULE4 & $\begin{array}{l}\text { Protein FAM184B OS=Homo sapiens OX=9606 } \\
\text { GN=FAM184B PE=2 SV=3 - [F184B_HUMAN] }\end{array}$ & F184B & 18 & 20 & 1.9 & -0.8 & 1.2 & -1.9 & -2.0 & -2.0 \\
\hline Q9UMS4 & $\begin{array}{l}\text { Pre-mRNA-processing factor } 19 \mathrm{OS}=\text { Homo sapiens } \\
\text { OX=9606 GN=PRPF } 19 \mathrm{PE}=1 \mathrm{SV}=1 \text { - } \\
\text { [PRP19_HUMAN] }\end{array}$ & PRP19 & 2 & 3 & 0.2 & -1.3 & -1.2 & -0.3 & -1.5 & -0.1 \\
\hline Q9UNM6 & $\begin{array}{l}\text { 26S proteasome non-ATPase regulatory subunit } 13 \\
\text { OS }=\text { Homo sapiens OX }=9606 \mathrm{GN}=\mathrm{PSMD} 13 \mathrm{PE}=1 \\
\mathrm{SV}=2-[\mathrm{PSD} 13 \text { HUMAN] }\end{array}$ & PSD13 & 1 & 1 & -0.2 & -1.2 & -0.9 & -1.8 & -1.5 & -2.3 \\
\hline Q9UQ05 & $\begin{array}{l}\text { Potassium voltage-gated channel subfamily } \mathrm{H} \text { member } 4 \\
\mathrm{OS}=\mathrm{Homo} \text { sapiens OX }=9606 \mathrm{GN}=\mathrm{KCNH} 4 \mathrm{PE}=2 \mathrm{SV}=1 \\
-[\mathrm{KCNH} 4 \text { HUMAN] }\end{array}$ & KCNH4 & 11 & 13 & -0.2 & -4.0 & -6.6 & 0.9 & -2.6 & -0.9 \\
\hline Q9Y230 & $\begin{array}{l}\text { RuvB-like } 2 \text { OS }=\text { Homo sapiens OX=9606 } \\
\text { GN=RUVBL2 PE }=1 \text { SV }=3-[\text { RUVB2_HUMAN] }\end{array}$ & RUVB2 & 6 & 8 & 0.2 & -1.6 & -1.3 & -0.5 & -1.1 & 0.2 \\
\hline Q9Y265 & $\begin{array}{l}\text { RuvB-like } 1 \text { OS=Homo sapiens OX=9606 } \\
\text { GN=RUVBL1 PE=1 SV=1 - [RUVB1 HUMAN] }\end{array}$ & RUVB1 & 3 & 5 & 0.2 & -1.4 & -1.2 & 2.7 & -3.3 & -0.3 \\
\hline Q9Y617 & $\begin{array}{l}\text { Phosphoserine aminotransferase OS=Homo sapiens } \\
\text { OX=9606 GN=PSAT1 PE }=1 \mathrm{SV}=2 \text { - [SERC HUMAN] }\end{array}$ & SERC & 1 & 2 & -0.6 & -1.2 & -0.9 & -2.0 & -1.5 & -1.1 \\
\hline Q2TB90 & $\begin{array}{l}\text { Putative hexokinase HKDC1 OS=Homo sapiens } \\
\text { OX=9606 GN=HKDC1 PE }=1 \mathrm{SV}=3 \text { - } \\
{[\text { HKDC1 HUMAN] }}\end{array}$ & HKDCl & 14 & 18 & 1.0 & 0.1 & 1.5 & 1.7 & -3.1 & -1.3 \\
\hline Q86YZ3 & $\begin{array}{l}\text { Hornerin OS }=\text { Homo sapiens OX=9606 GN=HRNR } \\
P E=1 \text { SV }=2-[\text { HORN_HUMAN] }\end{array}$ & HORN & 21 & 31 & -1.5 & -0.2 & -1.1 & 1.4 & -1.9 & -1.8 \\
\hline
\end{tabular}

Table 2. List of proteins expressed in the vero cells post infection, infection and gramicidin $S$ treatment and infection and melittin treatment for 24 and $48 \mathrm{~h}$ post infection.
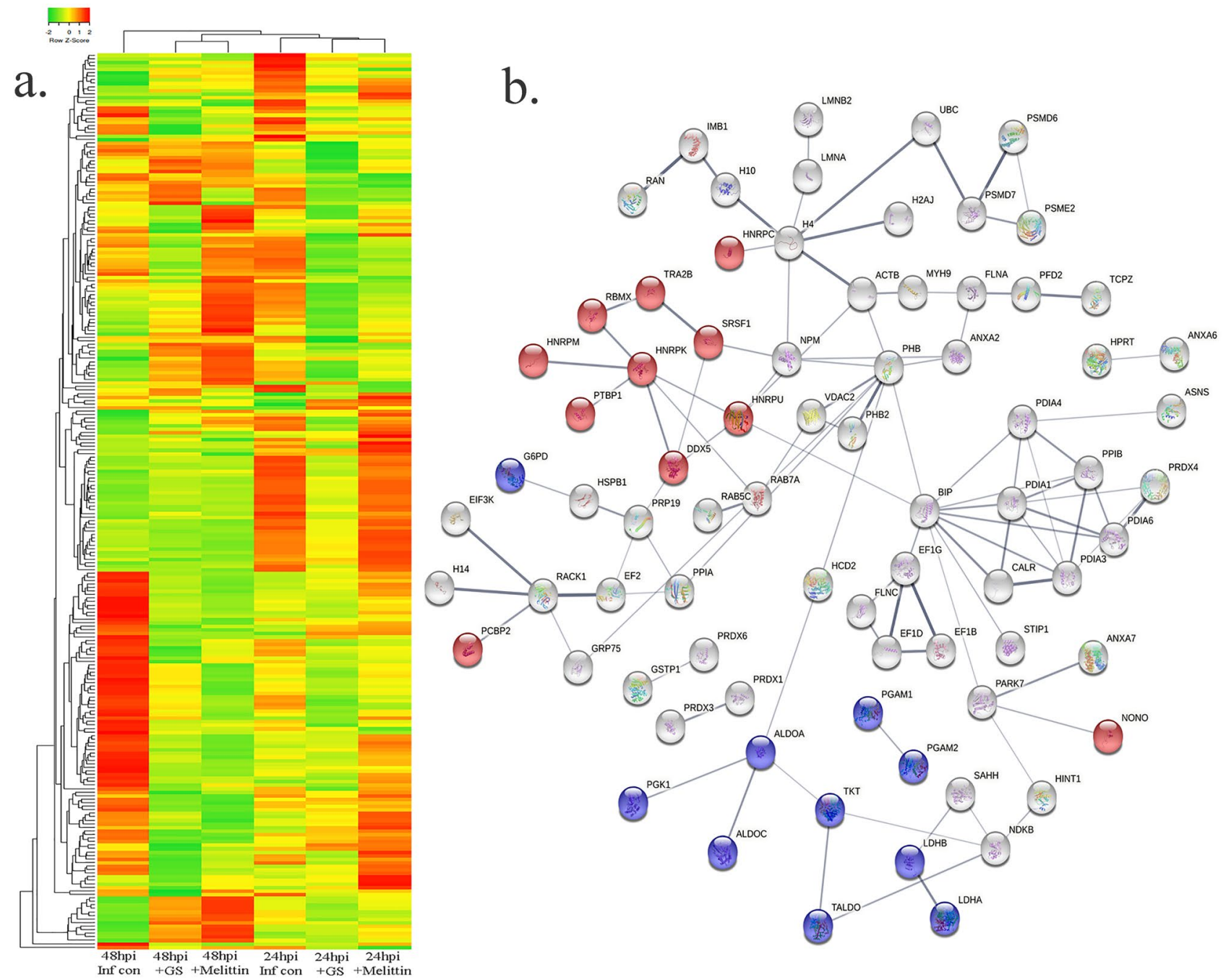

Figure 5. (a) Heat map expression of proteins in Vero cells post infection and peptide treatment. The image was created using web-enabled heatmapper software. (b) Network pathway analysis of the differentially expressed protein based on STRING analysis. The image was created using web-enabled STRING v11 software. 

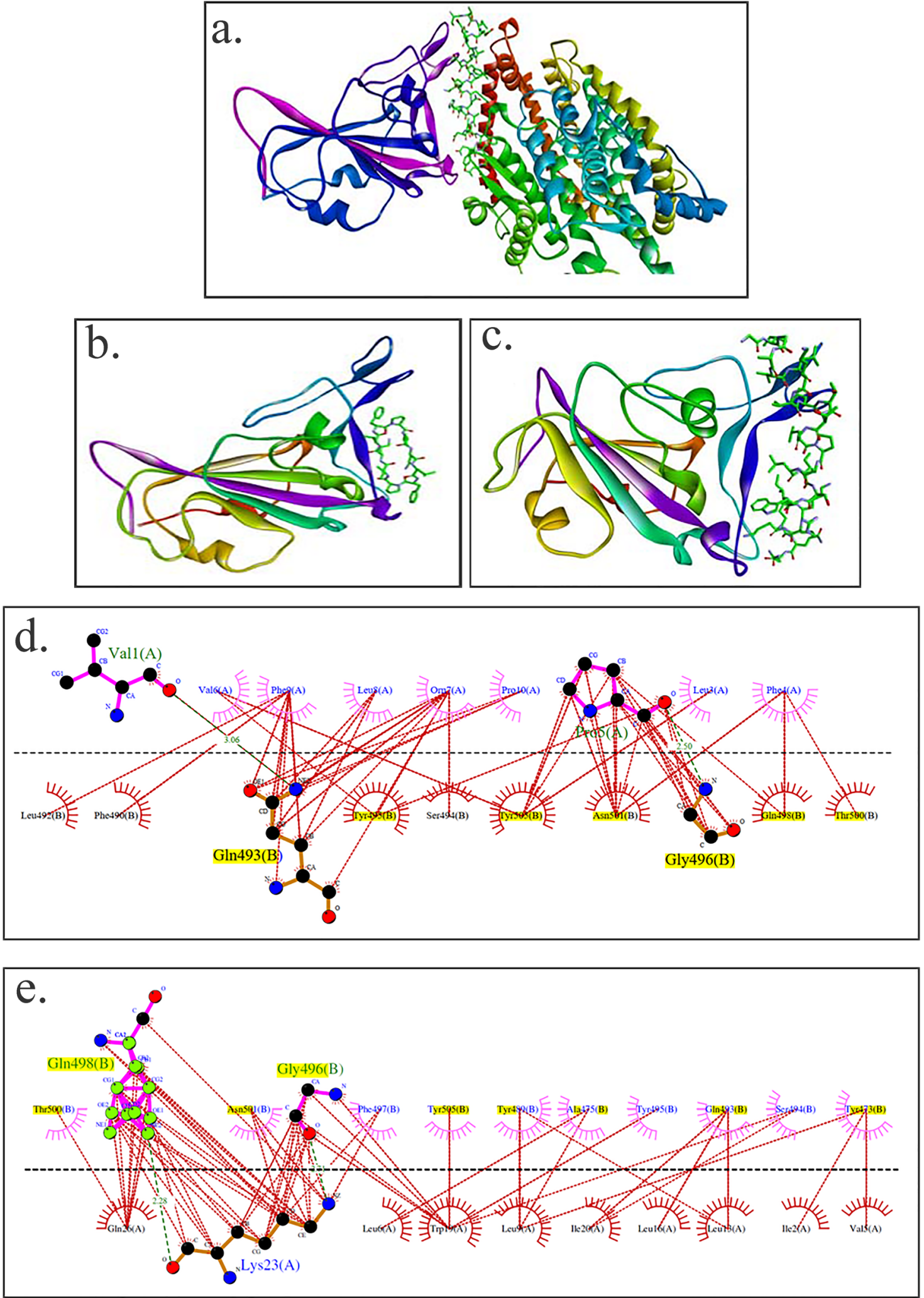

Figure 6. Structures of RBD of spike proteins and peptides and RBD binding region of ACE 2. (a) RBD and ACE, (b) RBD and gramicidin S, (c) RBD and melittin. The ACE2 binding region in RBD is colored violet. In ACE2, gramicidin S and melittin, the peptide regions binding to RBD are represented as sticks. LigPlots of interaction between ACE2 binding domain of the spike protein and (d) gramicidin S and (e) melittin. The residues of the RBD involved in binding to ACE2 are in yellow. The structures in panel $(\mathbf{a}-\mathbf{c})$ were generated using Discovery Studio v19.1.0.18287. The figures in panel (d, e) were generated using LigPlot. 
other viral infections. In case of HIV, drugs specific to the virus has been effective to treat the disease although there is still no effective vaccine. Likewise, malaria can be treated with specific drugs rather than vaccines.

However, development of specific therapeutic antiviral drugs for clinical use in a short span is extremely challenging. Repurposing of drugs already known for their therapeutic effects have been extensively screened and tested for inhibition of SARS-CoV-2 $2^{1,6}$. While many repurposed drugs have shown excellent anti SARS-CoV-2 activity in vitro, they have shown very little success when used clinically. We have shown that host defence peptide such as $\beta$-defensins may have a role in infection by SARS-CoV-2 as they are down regulated in COVID-19 patients $^{31}$.

Bee venom has immunosuppressive activity and is generally used in contemporary medicine to treat Multiple Sclerosis, Parkinson's disease, and arthritis. Bee venom activates foxP3-expressing cells, CD25 and CD4+ T cells, and thus modulates the IgE antibody ratio, resulting in a variety of allergic reactions to antigens ${ }^{32}$. This immunosuppressive activity was observed in Wuhan beekeepers against COVID-19 ${ }^{32}$. Melittin is the main component of bee venom, and it is active against both enveloped and non-enveloped viruses by activating the Toll-like receptors (TLRs) pathway, which reduces inflammatory cytokines like nuclear factor-kappa B (NF-kB), extracellular signal-regulated kinases (ERK1/2), and protein kinase $\mathrm{Akt}^{32}$. Melittin exhibited antiviral activity against several viruses in vitro ${ }^{18}$. Significant antiviral activity of the sitagliptin and melittin-nanoconjugates complex (IC50 value$8.439 \mu \mathrm{M}$ ) was observed against SARS-CoV-2 in vitro ${ }^{19}$. Binding of sitagliptin and melittin nano conjugates to the active site of SARS-CoV-2 3CLpro (a protease) was also observed through molecular docking ${ }^{19}$.

Gramicidin $S$ has potent antibacterial and fungicidal activity ${ }^{13}$. Molecular docking revealed that gramicidin $\mathrm{S}$ has a binding affinity of $11.4 \mathrm{kcal} / \mathrm{mol}$ to the SARS-CoV-2 spike glycoprotein and SARS-CoV-2 papain like protease, implying that gramicidin $S$ could be an effective drug against the SARS-CoV-2 virus ${ }^{33}$. SARS-CoV-2 is an enveloped virus, with the viral membrane essential for its integrity and function ${ }^{1,10}$. We reasoned that membrane-active peptides would disrupt the viral membrane and render the virus ineffective. We have investigated the anti-SARS-CoV-2 activity of two well studied membrane-active antibacterial peptides gramicidin $S$ and melittin.

Our present in vitro studies using gramicidin $S$ and melittin showed $\mathrm{EC}_{50}$ value of $1.571 \mu \mathrm{g}$ for gramicidin $S$ and $0.656 \mu$ g for melittin (Fig. 1). The results were comparable with remdesivir which we used as the assay control in our study (Fig. 5). The immunofluorescence studies are in agreement with our RT-qPCR data showing the decrease in the viral load in the gramicidin $S$ and melittin treated experimental groups compared to peptide non treated group (Fig. 4). Molecular docking studies suggest that both the peptides have structural features that would favor binding to RBD of the spike protein (Fig. 6). ZDOCK used in the present study, has been used extensively to study protein-protein/peptide interactions ${ }^{34}$. However, our prediction that melittin and gramicidin $S$ have structural features that favor interaction with RBD needs experimental validation. In fact, membraneactive antibacterial peptides have multiple targets in bacteria. It is conceivable that gramicidin $S$ and melittin also have multiple targets on the virus thereby acting as an effective antiviral agent. Both gramicidin $S$ and melittin have hemolytic activity at concentrations higher than the EC50 values reported in this study. Hemolytic activity can be attenuated or eliminated by engineering the peptide for specific antiviral activity. This approach has been successfully used in generating gramicidin $S$ and melittin analogs with only antibacterial activity without any hemolytic activity ${ }^{35,36}$. In order to prevent off-target toxic effects of melittin, formulations with polymeric nanoparticles are being explored ${ }^{37}$. Formulations for use of peptides as therapeutics is a challenge but there are considerable efforts towards this goal ${ }^{12}$.

Proteomics studies indicate that metabolic change caused by SARS-CoV-2 pathogenesis result in long-term metabolic disorders in COVID-19 patients, and this varies according to pathogen severity. Carbon sources, specifically glycolysis and glutamino lysis pathways, have been found to play critical roles in SARS-CoV-2 viral replication and production ${ }^{38}$. Non-oxidative pentose phosphate pathways (PPP) are also involved in viral replication; Transketolase is a key mediator enzyme of PPP involved in ribonucleotide production. Benfo-oxythiamine, a TKT inhibitor, acted against SARS-CoV-2 infection and inhibited the viral replication ${ }^{39}$. Our findings from proteomic pathway analysis showed that several proteins are strongly associated with carbon metabolism and non-oxidative PPP. Specifically, LDHA, LDHB, ALDOA, TALDO, PGK1, and PGAM2 proteins were found to be up regulated in early viral replication, i.e. at $24 \mathrm{~h}$ viral induced cell control, and vice versa in gramicidintreated cells. TKT was found to be up regulated after $48 \mathrm{~h}$ of viral induced cell control, but it was substantially down regulated by melittin treatment. It suggests that gramicidin and melittin may function as viral inhibitors by suppressing intercellular metabolic regulators.

Another prominent pathway, mRNA processing, was identified during the local network pathway analysis. According to a recent study on SARS-CoV-2 RNA host protein interaction, the majority of virus which induced host RNA binding proteins prevents the virus induced cell death. Several mRNA binding proteins, including Heterogeneous nuclear ribonucleoproteins (HNRNPs), dead box RNA helicases (DDX), and NONO, were activated during the innate immune response to SARS-CoV-2 infection ${ }^{40}$. In our study, NONO, DDX5, RBMX, and HNRPM proteins were found to be up regulated with more than 1 log fold change in melittin-treated SARSCoV-2 infected cells. This finding suggests that melittin may have antiviral activity during the early stages of viral infection by activating host RNA binding proteins.

The antimicrobial activity of gramicidin $S$ and melittin have been well characterized. Our results strongly argue for development of peptides, gramicidin $S$ and melittin, as potent therapeutic candidates to treat SARS$\mathrm{CoV}-2$ and possibly other influenza like viruses which are also enveloped viruses, for which there are no effective vaccines. Localized delivery at the site of infection in the nasopharyngeal region by appropriate formulations would avoid cytotoxicity due to systemic delivery.

In conclusion, our study indicates the potential of antibacterial peptides such as gramicidin $\mathrm{S}$ and melittin for development as therapeutic molecules to treat COVID19. These peptides have broad-spectrum antibacterial activity and resistance does not develop against them. It is likely that variants of SARS-CoV-2 which may escape immune surveillance, may be susceptible to membrane-active peptides such as gramicidin $S$ and melittin. 
With tremendous advances in the formulation of drugs to minimize side-effects, it should be able to administer gramicidin $S$ and melittin by appropriate formulations to avoid any non-specific cytolytic effects.

\section{Materials and methods}

Peptides. Gramicidin S and melittin were procured from commercial sources (Gramicidin S: 368108, Calbiochem CA, USA Melittin: M4171 from Sigma Chemical Co, USA). They were characterized by HPLC and mass spectrometry and found to be $>95 \%$ pure.

Cell viability using MTT assay. The Vero cells were plated in 96 well culture plate and incubated at $37^{\circ} \mathrm{C}$ with $5 \% \mathrm{CO}_{2}$. After attaining 90-95\% cell confluency, different concentrations of gramicidin $\mathrm{S}$ and melittin $(0.5$, $0.7,3,5 \mu \mathrm{g}$ for both) were added to the cells to check the effect of the peptides on the cells for $24 \mathrm{~h}$. After $24 \mathrm{~h}$, $100 \mu \mathrm{l}(50 \mu \mathrm{g})$ of MTT substrate was added to the cells and the plate was continued to incubate for $3 \mathrm{~h}$ at $37^{\circ} \mathrm{C}$ with $5 \% \mathrm{CO}_{2}$. Later the formazan crystals formed were dissolved in $100 \mu$ of DMSO and the absorbance was measured at $570 \mathrm{~nm}$ in Multimode Micro plate reader (Synergy HIM).

RT-qPCR assay. The effect of gramicidin S and melittin was tested against the SARS-CoV-2 with different concentrations. Remdesivir was run as an assay control. The titers for the virus were adjusted such that there was only viral replication and no cytolysis. Briefly, the virus (MOI 0.1) was pre-incubated with different concentrations of gramicidin $\mathrm{S}$ and melittin $(0.1-10 \mu \mathrm{g})$ for an hour at $37^{\circ} \mathrm{C}$. After the incubation, virus inoculum containing gramicidin $S$ and melittin was added to the Vero cells in duplicates $(50 \mu \mathrm{l} /$ well). Remdesivir $(1 \mu \mathrm{M})$ was added to the Vero cells without pre-incubation as in the case of peptides. All the experimental groups were left for infection for $3 \mathrm{~h}$ while maintaining at $37^{\circ} \mathrm{C}$ with $5 \% \mathrm{CO}_{2}$. Post-infection (PI), media containing viral inoculum and the gramicidin $S$ and melittin was removed and replaced with $200 \mu$ of fresh DMEM media containing $10 \% \mathrm{FBS}$ and the experimental groups were maintained for varying time points in an incubator maintained at $37^{\circ} \mathrm{C}$ with $5 \% \mathrm{CO}_{2}$. Post-incubation, cell supernatants from the experimental groups were collected and spun for $10 \mathrm{~min}$ at $6000 \mathrm{~g}$ to remove debris and the supernatant was transferred to fresh collection tubes and later were processed to isolate viral RNA. RNA was extracted from $200 \mu \mathrm{L}$ aliquots of sample supernatant using the MagMAX $^{\mathrm{Tm}}$ Viral/Pathogen Extraction Kit (Applied Biosystems, Thermofisher). Briefly, the viral supernatants from the test groups were added into the deep well plate (KingFisher ${ }^{\mathrm{TM}}$ Thermo Scientific) along with a lysis buffer containing the following components-260 $\mu \mathrm{L}$, MagMAX ${ }^{\mathrm{su}}$ Viral/Pathogen Binding Solution; $10 \mu \mathrm{L}$, MVP-II Binding Beads; $5 \mu \mathrm{L}$, MagMAX ${ }^{\mathrm{TM}}$ Viral/Pathogen Proteinase-K, for $200 \mu \mathrm{L}$ of sample. (Extraction was performed using KingFisher Flex (version 1.01, Thermo Scientific) according to manufactures instructions). The eluted RNA was immediately stored in $-80^{\circ} \mathrm{C}$ until further use.

The detection of SARS-CoV-2 was done using COVID-19 RT-PCR Detection Kit (Fosun 2019-nCoV qPCR, Shanghai Fosun Long March Medical Science Co. Ltd.) according to the manufacturer's instructions. The kit detects Envelope gene (E; ROX labelled), Nucleocapsid gene (N-JOE labelled) and Open Reading Frame1ab (ORF1ab, FAM labelled) specific to SARS-CoV-2 for detection and amplification of the cDNA. SARS-CoV-2 cDNA (Ct 28) was used as a positive control. The log viral particles and a semi-log graph was plotted through the linear regression equation obtained using the RNA extracted from the known viral particles by RT-qPCR, using $\mathrm{N}$ - gene specific to SARS CoV-2 virus.

Immunocytochemistry. The Vero cells were seeded in 6-well plate with the sterile glass cover slips. Cells at $90-95 \%$ confluency were considered for SARS-CoV-2 infection. Briefly, gramicidin S and melittin, were preincubated with SARS-CoV-2 virus for $1 \mathrm{~h}$ at $37^{\circ} \mathrm{C}$ with $1.5 \mu \mathrm{g} / 100 \mu \mathrm{l}$ and $3 \mu \mathrm{g} / 100 \mu \mathrm{l}$ respectively. Later, the viral inoculum incubated with peptides were used to infect Vero cells on the glass coverslips. After $3 \mathrm{~h}$ of infection, the viral inoculum containing the peptides was replaced with fresh media with $10 \%$ FBS until 12 and $24 \mathrm{~h}$. Parallel controls were maintained without the drug treatment. After 12 and $24 \mathrm{~h}$, the treated and untreated cells were fixed with $4 \%$ paraformaldehyde and processed further for immunocytochemistry. The fixed samples were washed thrice with PBS and the cells were permeabilized using 0.3\% Triton X-100 (Sigma, cat. no.: X100; Lot no.: 056K0045) in PBS for $15 \mathrm{~min}$ at room temperature (RT). Then the cells were washed with PBS, thrice for 5 min each at RT. The cells were incubated with the 3\% Bovine Serum Albumin (BSA) (Sigma) in PBS, for $1 \mathrm{~h}$ at RT to block the nonspecific antibody binding. Later the experimental groups were incubated with the anti-sera for RBD of SARS-CoV-2 (1:200) prepared in 1\% BSA made in PBS (anti-sera against SARS-CoV-2 was raised in rabbits and validated using ELISA at CCMB) overnight at $4{ }^{\circ} \mathrm{C}$. After incubation the cells were washed with PBST, thrice at RT for 10 min each. Later the cells were incubated with the secondary anti-Rabbit IgG antibody conjugated with Alexa Fluor 488 (Life Technologies, Cat. no.: A11008; Lot no.: 1735088) at the dilution of 1:200 in 1\% BSA made in PBS. Rhodamine Phalloidin (Life Technologies, Cat. no.: R415; Lot no.: 1738179) was used to label F-actin. The cells were incubated with secondary antibody and Rhodamine phalloidin mix for $1 \mathrm{~h}$ at room temperature. After incubation the cells were washed with PBST, thrice at RT for 10 min each. Then, the cover slips containing the cells were mounted over the pre-cleaned slides using Vectashield mounting medium containing DAPI (for nuclear staining) (Vector Laboratories, Cat. no.: H-1200, Lot no.: ZC1216). Images were obtained using confocal microscope FV3000 with software version 2.4.1.198 (Olympus Life Sciences Solutions) in Light Scanning Microscopy (LSM) mode.

Proteomic analysis. Total protein was extracted from the control Vero cells, Vero cells infected with SARSCoV-2 and Vero cells infected with SARS-CoV-2 and treated with gramicidin S and melittin separately. The cells were collected at 24 and $48 \mathrm{~h}$ independently. The samples were centrifuged and pellet was dissolved in protein solubilisation buffer $\mathrm{r}^{41,42}$ and sonicated for $10 \mathrm{~min}$ at BSL3 lab facility. The protein samples were further 
centrifuged for $30 \mathrm{~min}$ at 14,000 RPM to remove the cell debris. Quantification of the pooled protein samples were performed using Amido Black method against BSA standard. A $200 \mu \mathrm{g}$ of total protein from all the experimental groups were electrophoresed in 10\% SDS-PAGE, Commassie R250 stained, destained and gel excised in to four fractions based on molecular weight. In-gel trypsin digestion and iTRAQ labeling and purification were performed as described earlier ${ }^{42-44}$. iTRAQ label was labelled as 114-Control; 115-Infection; 116-Infected cells treated with Melittin and 117-Infected cells treated with gramicidin S. All labelled peptides were pooled and purified by running through C18 column. Peptides were reconstituted in 5\% acetonitrile (ACN) \& $0.2 \%$ formic acid and then subjected to the Liquid Chromatography Mass Spectrometry (LCMS/MSMS) analysis in OrbitrapVelos Nano analyzer (Q-Exactive HF). The proteomic data obtained from the mass spectrometer were analysed against human proteome and SARS-CoV-2 proteome data. All the obtained proteome data were tabulated and differential expression in SARS-CoV-2 proteins were estimated against the control negative samples. The obtained proteome data was analysed for its heat map expression profile using heatmapper software ${ }^{45}$ (www. heatmapper.ca). Network and pathway analysis of the associated proteins were performed using STRING v11.5 ${ }^{46}$ (https://string-db.org).

Molecular docking. The receptor binding domain (RBD) of the SARS-CoV-2 spike protein was obtained by editing the crystal structure of the C-terminal domain of the SARS-CoV-2 spike protein in complex with human ACE2 (PDB id: 6zlg) ${ }^{47}$. The ID of the structure used for gramicidin S monomer is CCDC 626343. Monomeric melittin structure was obtained by editing the crystal structure of tetrameric melittin (PDB id: $2 \mathrm{mlt}$ ). The structures were generated using Discovery Studio v19.1.0.18287 (2019). Interactions between amino acids were visualized using LigPlot $^{28}$.

Statistical analysis. All the experiments were performed in duplicates with technical replicates $(n=6)$. The data analysis and graphs were generated using GraphPad Prism (Ver 8.4.2). All the values were represented as mean \pm SD.

Ethics approval. The Anti-SARS CoV-2 study was approved from Institutional Bio-safety Committee of CSIR-Centre for Cellular and Molecular Biology, Hyderabad, India.

Received: 23 October 2021; Accepted: 16 February 2022

Published online: 02 March 2022

\section{References}

1. Chilamakuri, R. \& Agarwal, S. COVID-19: Characteristics and therapeutics. Cells 10, 206 (2021).

2. Creech, C. B., Walker, S. C. \& Samuels, R. J. SARS-CoV-2 vaccines. JAMA 325, 1318-1320 (2021).

3. Bok, K., Sitar, S., Graham, B. S. \& Mascola, J. R. Accelerated COVID-19 vaccine development: Milestones, lessons, and prospects. Immunity 54, 1636-1651 (2021).

4. Hacisuleyman, E. et al. Vaccine breakthrough infections with SARS-CoV-2 variants. N. Engl. J. Med. 384, 2212-2218 (2021).

5. Taylor, P. C. et al. Neutralizing monoclonal antibodies for treatment of COVID-19. Nat. Rev. Immunol. 1, 382-393 (2021).

6. Dittmar, M. et al. Drug repurposing screens reveal cell-type-specificentry pathways and FDA-approved drugs active against SARSCov-2. Cell Rep. 35, 108959 (2021).

7. Gao, K., Nguyen, D. D., Chen, J., Wang, R. \& Wei, G. Repositioning of 8565 existing drugs for COVID-19. J. Phys. Chem. Lett. 11, 5373-5382 (2020).

8. Yan, V. C. \& Muller, F. L. Why remdesivir failed: Preclinical assumptions overestimate the clinical efficacy of remdesivir for COVID19 and ebola. Antimicrob. Agents Chemother. 65, e01117-e1121 (2021).

9. Ledford, H. COVID antiviral pills: What scientists still want to know. Nature 599, 358-359 (2021).

10. Hu, B., Guo, H., Zhou, P. \& Shi, Z. L. Characteristics of SARS-CoV-2 and COVID-19. Nat. Rev. Microbiol. 19, 141-154 (2021).

11. Sitaram, N. \& Nagaraj, R. Interaction of antimicrobial peptides with biological and model membranes: Structural and charge requirements for activity. Biochim. Biophys. Acta 1462, 29-54 (1999).

12. Mahlapuu, M., Björn, C. \& Ekblom, J. Antimicrobial peptides as therapeutic agents: Opportunities and challenges. Crit. Rev. Biotechnol. 40, 978-992 (2020).

13. Prenner, E. J., Lewis, R. N. A. H. \& McElhaney, R. N. The interaction of the antimicrobial peptide gramicidin S with lipidbilayer model and biological membranes. Biochem. Biophys. Acta. 1462, 201-221 (1999).

14. Raghuraman, H. \& Chattopadhyay, A. Melittin: A membrane-active peptide with diversefunctions. Biosci. Rep. 27, 189-223 (2007).

15. Tonk, M., Ružek, D. \& Vilcinskas, A. Compelling evidence for the activity of antiviral peptides against SARS-CoV-2. Viruses 13, $912(2021)$

16. Mahendran, A. S. K., Lim, Y. S., Fang, C.-M., Loh, H.-S. \& Le, C. F. The potential of antiviral peptides as COVID-19 therapeutics. Front. Pharmacol. 11, 575444 (2020).

17. Ghosh, S. K. \& Weinberg, A. Ramping up antimicrobial peptides against severe acute respiratory syndrome coronavirus-2. Front. Mol. Biosci. 8, 620806 (2021).

18. Memariani, H., Memariani, M., Moravvej, H. \& Shahidi-Dadras, M. Melittin: A venom-derived peptide with promising anti-viral properties. Eur. J. Clin. Microbiol. Infect. Dis. 39, 5-17 (2020).

19. Al-Rabia, M. W. et al. Repurposing of sitagliptin-melittin optimized nanoformula against sars-cov-2: Antiviral screening and molecular docking studies. Pharmaceutics 13, 307 (2021).

20. Hossen, M., Gan, S. H. \& Khalil, M. Melittin, a potential natural toxin of crude bee venom: probable future arsenal in the treatment of diabetes mellitus. J. Chem. 2017, 1-10 (2017).

21. Duffy, C. et al. Honeybee venom and melittin suppress growth factor receptor activation in HER2-enriched and triple-negative breast cancer. NPJ Precis. Oncol. 4, 24 (2020).

22. Berditsch, M., Lux, H., Babii, O., Afonin, S. \& Ulrich, A. S. Therapeutic potential of GramicidinS in the treatment of root canal infections. Pharmaceuticals 9, 56 (2016).

23. Hood, J. L., Jallouk, A. P., Campbell, N., Ratner, L. \& Wickline, S. A. Cytolytic nanoparticles attenuate HIV-1 infectivity. Antivir. Ther. 18, 95-103 (2013).

24. Uddin, M. B. et al. Inhibitory effects of bee venom and its components against viruses in vitro and in vivo. J. Microbiol. 54, 853-866 (2016). 
25. Swierstra, J., Kapoerchan, V., Knijnenburg, A., van Belkum, A. \& Overhand, M. Structure, toxicity and antibiotic activity of gramicidin S and derivatives. Eur. J. Clin. Microbiol. Infect. Dis. 35, 763-769 (2016).

26. Askari, P., Namaei, M. H., Ghazvini, K. \& Hosseini, M. In vitro and in vivo toxicity and antibacterial efficacy of melittin against clinical extensively drug-resistant bacteria. BMC Pharmacol. Toxicol. 22, 42 (2021).

27. Pierce, B. G. et al. ZDOCK server: Interactive docking prediction of protein-protein complexes and symmetric multimers. Bioinformatics 30(12), 1771-1773 (2014).

28. Laskowski, R. A. \& Swindells, M. B. LigPlot+: Multiple ligand-protein interaction diagrams for drug discovery. J. Chem. Inf. Model. 51, 2778-2786 (2011).

29. Coleman, C. M. \& Frieman, M. B. Coronaviruses: Important emerging human pathogens. J. Virol. 88, 5209-5212 (2014).

30. Zhu, Z. et al. From SARS and MERS to COVID-a brief summary and comparison of severe acute respiratory infections caused by three highly pathogenic human corona viruses. Respir. Res. 21, 224 (2020).

31. Idris, M. M., Banu, S., Siva, A. B. \& Nagaraj, R. Down regulation of defensin genes in SARS-CoV-2 infection. MedRxiV https:// doi.org/10.1101/2020.09.21.20195537 (2020).

32. Kasozi, K. I. et al. Bee venom: A potential complementary medicine candidate for SARS-CoV-2 infections. Front. Public Health 8 , 75 (2020).

33. Bansal, P., Kumar, R., Singh, J. \& Dhanda, S. In silico molecular docking of SARS-CoV-2 surface proteins with microbial nonribosomal peptides: Identification of potential drugs. J. Proteins Proteom. 1, 1-8 (2021).

34. Huang, S. Y. Exploring the potential of global protein-protein docking: An overview and critical assessment of current programs for automatic ab initio docking. Drug. Discov. Today 20, 969-977 (2015).

35. Juvvadi, P., Vunnam, S. \& Merrifield, R. B. Synthetic melittin, its enantio, retro, and retroenantio isomers, and selected chimeric analogs: Their antibacterial, hemolytic, and lipid bilayer action. J. Am. Chem. Soc. 118, 8989-8997 (1996).

36. Guan, Q. et al. Recent advances in the exploration of therapeutic analogues of gramicidin s, an old but still potent antimicrobial peptide. J. Med. Chem. 62, 7603-7617 (2019).

37. Lv, S., Sylvestre, M., Song, K. \& Pun, S. H. Development of D-melittin polymeric nanoparticles for anti-cancer treatment. Biomaterials 277, 121076 (2021).

38. Krishnan, S. et al. Metabolic perturbation associated with COVID-19 disease severity and SARS-CoV-2 replication. Mol. Cell Proteom. https://doi.org/10.1101/2021.02.24.432759 (2021).

39. Bojkova, D. et al. Targeting pentosephosphate pathway for SARS-CoV-2 therapy. Metabolites 11, 669 (2021).

40. Flynn, R. A. et al. Discovery and functional interrogation of SARS-CoV-2 RNA-host protein interactions. Cell 184, 2394-2411 (2021).

41. Saxena, S. et al. Proteomic analysis of zebrafish caudal fin regeneration. Mol. Cell. Proteom. 111, 014118 (2012).

42. Purushothaman, S. et al. Transcriptomic and proteomic analyses of Amphiurafiliformis arm tissue-undergoing regeneration. J. Proteomics. 112, 113-124 (2015).

43. Nagumantri, S. P., Banu, S. \& Idris, M. M. Transcriptomic and proteomic analysis of Hemidactylusfrenatus during initial stages of tail regeneration. Sci Rep. 11, 3675 (2021).

44. Banu, S. et al. Understanding the complexity of Epimorphic Regeneration in zebrafish: A Transcriptomic and Proteomic approach. BioRxiv. 76, 429 (2021).

45. Babicki, S. et al. Heatmapper: Web-enabled heat mapping for all. Nucleic Acids Res. 44(W1), W147-W153 (2016).

46. Szklarczyk, D. et al. STRING v11: Protein-protein association networks with increased coverage, supporting functional discovery in genome-wide experimental datasets. Nucleic Acids Res. 47, D607-613 (2019).

47. Wang, Q. et al. Structural and functional basis of SARS-CoV-2 entry by using human ACE2. Cell 181, 894-904 (2020).

\section{Acknowledgements}

BKK would like to acknowledge financial support from Council of Scientific and Industrial Research (CSIR MLP0056). RN is Indian National Academy (INSA) Senior Scientist. The authors are thankful to Ms. Noorul Fowzia for critically reviewing the manuscript.

\section{Author contributions}

M.G.E., Y.P., S.B. and S.R.-Performed the experiment. M.G.E., Y.P., S.B., S.R., R.N., B.K. and M.M.I. analyzed the data. M.G.E., Y.P., S.B., R.N., B.K. and M.M.I. wrote the manuscript.

\section{Competing interests}

The authors declare no competing interests.

\section{Additional information}

Correspondence and requests for materials should be addressed to B.K.K. or M.M.I.

Reprints and permissions information is available at www.nature.com/reprints.

Publisher's note Springer Nature remains neutral with regard to jurisdictional claims in published maps and institutional affiliations.

Open Access This article is licensed under a Creative Commons Attribution 4.0 International License, which permits use, sharing, adaptation, distribution and reproduction in any medium or format, as long as you give appropriate credit to the original author(s) and the source, provide a link to the Creative Commons licence, and indicate if changes were made. The images or other third party material in this article are included in the article's Creative Commons licence, unless indicated otherwise in a credit line to the material. If material is not included in the article's Creative Commons licence and your intended use is not permitted by statutory regulation or exceeds the permitted use, you will need to obtain permission directly from the copyright holder. To view a copy of this licence, visit http://creativecommons.org/licenses/by/4.0/.

(C) The Author(s) 2022 